\title{
AUNC
}

Zabytkoznawstwo i Konserwatorstwo XLIX

Toruń 2018

\section{Próba określenia kierunku zmian kolorystyki warstw malarskich obrazu „Ukrzyżowanie” Pietera Coecke'a van Aelst (1502-1550) z Muzeum Narodowego w Warszawie*}

\author{
MONIKA KĘSY \\ konserwator dzieł sztuki \\ e-mail: monika@blue-gin.net \\ ELŻBIETA SZMIT-NAUD
Zakład Konserwacji Malarstwa i Rzeźby Polichromowanej
Wydział Sztuk Pięknych, UMK w Toruniu
e-mail: esn@umk.pl
ORCID: 0000-0002-5040-9723

\section{JUSTYNA OLSZEWSKA-ŚWIETLIK} \\ Zakład Technologii i Technik Malarskich \\ Wydział Sztuk Pięknych, UMK w Toruniu \\ e-mail: justolsz@umk.pl \\ ORCID: 0000-0001-5892-8619
}

Key words: Pieter Coecke van Aelst, $16^{\text {th }}$ century panel painting, lightfastness tests, colour change of paint layers, pigment mixtures lightfastness, National Museum in Warsaw

Słowa kluczowe: Pieter Coecke van Aelst, malarstwo tablicowe XVI wieku, badania starzeniowe, zmiany kolorystyki warstw malarskich, światłotrwałość mieszanin pigmentów, Muzeum Narodowe w Warszawie

\footnotetext{
Abstract

An attempt to determine the direction of changes in the color of paint layers of the Crucifixion by Pieter Coecke van Aelst (1502-1550) from National Museum in Warsaw

The article attempts to determine the direction of changes in the color of the painting layers of the Crucifixion by Pieter Coecke van Aelst (1502-1550), which is in the col-
} 
lections of the National Museum in Warsaw. Based on the results of comprehensive research of image technique and technology, samples of painting layers containing identified pigments and adhesives were made. The research involved sixteen sets of samples in two types of binders: oil and temper. The samples were subjected to lightfastness tests in imitation conditions prevailing in the museum interiors and were made instrumental measurements of color before and after aging were performed. Analysis of color change results was considered in the CIE $\mathrm{L}^{*} \mathrm{a} * \mathrm{~b}$ * color space and CIE $L * C * h *$. The direction of changes in the examined sets was compared visually with the current state of preservation of the Crucifixion.

\section{Streszczenie}

W artykule podjęta została próba określenia kierunku zmian kolorystyki warstw malarskich obrazu Ukrzyżowanie Pietera Coecke'a van Aelst (1502-1550), który znajduje się w zbiorach Muzeum Narodowego w Warszawie. Na podstawie wyników kompleksowych badań techniki i technologii obrazu wykonano próbki warstw malarskich zawierających zidentyfikowane pigmenty i spoiwa. Badaniami objęto szesnaście zestawów próbek w dwóch rodzajach spoiw: olejnym oraz temperowym. Wykonane próbki poddano sztucznemu starzeniu pod wpływem światła w środowisku imitującym warunki panujące we wnętrzach muzealnych oraz wykonano instrumentalne pomiary barwy przed i po starzeniu. Analiza wyników zmian barwy rozpatrywana była w przestrzeni barwnej CIE L*a*b* oraz CIE L*C*h*. Kierunek zmian w badanych zestawach porównywano wizualnie z obecnym stanem zachowania obrazu Ukrzyżowanie.

\section{Wprowadzenie}

Niniejszy tekst prezentuje próbę określenia kierunku zmian kolorystycznych, jakie zaszły w toku dziejów w warstwach malarskich obrazu Ukrzyżowanie autorstwa Pietera Coecke'a van Aelst z kolekcji Muzeum Narodowego w Warszawie $^{1}$. Obraz powstał w drugiej ćwierci XVI wieku, jednak pod względem użytych do jego wykonania materiałów oraz techniki malarskiej wpisuje się w tradycję piętnastowiecznego malarstwa niderlandzkiego ${ }^{2}$. Obecny wygląd dzieła, w wyniku postępującego procesu starzenia się materiałów oraz licznych interwencji konserwatorskich, odbiega od pierwotnego.

1 Hanna Benesz i Maria Klug, Early Netherlandish, Dutch, Flemish and Belgian Paintings 1494-1983 in the Collections of the National Museum on Warsaw and the Palace at Nieborów. Complete Illustrated Summary Catalogue, t. 1 Signed and Attributed Paintings, red. Agnieszka Morawińska (Warsaw: The National Museum in Warsaw, 2016), 136. Obraz został użyczony do badań budowy technicznej przez Muzeum Narodowe w Warszawie, za co autorzy dziękują.

2 Zob. Monika Kęsy, Obraz 'Ukrzyżowanie' Pietera Coecke’a van Aelst (1502-1550) - analiza technologii i techniki malarskiej jako przyczynek do określenia zmian pierwotnej kolorystyki dzieła (praca magisterska, pod kierunkiem prof. dr hab. Justyny Olszewskiej-Świetlik, UMK w Toruniu, 2017). 
Obraz został namalowany na drewnianym podobraziu, na które składa się siedem dębowych desek sklejonych na styk. Na całą powierzchnię położono zaprawę kredowo-klejową z niewielkim dodatkiem bieli ołowiowej. Na wygładzonej zaprawie opracowano odręcznie, przy użyciu pędzla, rysunek czernią kostną w spoiwie wodnym. Na całość położono izolację olejną. Modelunek malarski wykonano w technice wielowarstwowej z podmalowaniem i wykończeniem laserunkiem w technice olejnej i olejno-żywicznej. Na paletę malarską składają się: biel ołowiowa, w tym jej odmiana nazywana cerrusą, żółcień cynowo-ołowiowa, żółcień organiczna, żółte, czerwone i brązowe pigmenty żelazowe pochodzenia naturalnego, azuryt naturalny, malachit, zieleń miedziowa, czerń kostna, czerń roślinna, czerwień organiczna - kraplak, kermes lub karmin (?).

Obraz w przeszłości w wyniku naturalnych procesów starzeniowych oraz niekorzystnych warunków przechowywania uległ zniszczeniom. Dotyczą one zarówno podobrazia, jak i zaprawy z warstwą malarską. Na bocznych powierzchniach podobrazia widoczny jest szereg okrągłych otworów wylotowych pozostawionych przez owady. Z powodu rozległych zniszczeń w trakcie wcześniejszych zabiegów konserwatorskich drewno podobrazia zostało ścienione do grubości około $0,6 \mathrm{~cm}$. W tym samym czasie podobrazie zostało zabezpieczone i wzmocnione od odwrocia gęstym, dębowym parkietażem. Pomimo tych zabiegów owady żerowały w drewnie jeszcze przez pewien czas, o czym świadczy obecność otworów wylotowych na bocznych powierzchniach desek parkietażu. Zaprawa wraz z warstwą malarską silnie popękała - na całej powierzchni obrazu jest widoczna gęsta siatka spękań. Spowodowały je ruchy drewnianego podobrazia, które kurcząc się i rozszerzając wywoływało pęknięcia niewystarczająco elastycznej zaprawy, warstwy malarskiej oraz późniejszego zabezpieczenia woskowego. Najbardziej zauważalne i najgłębsze spękania występują w jasnych partiach karnacji, białych i jasnych elementach odzieży oraz w jasnych partiach nieba. Siatkowe spękania są typowe dla warstwy malarskiej z dużą ilością bieli ołowiowej. Zaprawa w wielu miejscach jest odspojona, rozległe ubytki znajdują się na łączeniach desek. Ubytki zaprawy zostały uzupełnione kitami emulsyjnymi, w składzie których zidentyfikowano biel ołowiową. Znacznie uszkodzone są partie tła pomiędzy figurami Marii Magdaleny i Jana Ewangelisty oraz jego czerwony płaszcz. Wiele ubytków powstało na krawędziach obrazu z powodu złego zamocowania ramy, która ocierała się o warstwę malarską. 
W przeszłości ubytki warstwy malarskiej uzupełniono imitatorsko. Zastosowano następujące pigmenty: biel cynkową, żółcień żelazową, żółcień cynkową, czerwień żelazową, czerwień organiczną, ultramarynę sztuczną, indygo, błękit kobaltowy, ceruleum, a także tlenek chromu. Uzupełnienia te stanowią około $20 \%$ powierzchni obrazu (il. 1). Oryginalny werniks ścieniono i położono wtórny. Dodatkowo na powierzchnię obrazu naniesiono warstwę wosku, który pożółkł i popękał.

Podobrazie oprawione jest w nieoryginalną pozłacaną, dekoracyjną ramę $\mathrm{z}$ błękitnymi laserunkami. Wtórna rama nie jest integralnie związana z obrazem, nałożona została na lico, a od odwrocia przymocowana metalowymi blaszkami, które opierają się o parkietaż i przytrzymują ją przy powierzchni obrazu.

Warstwa malarska wydaje się znacząco zmieniona kolorystycznie. Niektóre jej partie są złuszczone (np. bardzo zniszczone czerwienie - suknia Marii zachowana jest szczątkowo; il. 1) lub przemalowane (np. błękity płaszcza Marii). Wiele ubytków warstwy malarskiej znajduje się także na łączeniach desek, w największym stopniu w partiach brązów, zieleni oraz szat świętych. Różnice kolorystyczne są dostrzegalne zarówno w obrębie oryginalnych, jak i wtórnych materiałów.

Znane są różne możliwe kierunki zmian kolorystyki warstw malarskich będących następstwem procesu starzenia podczas ekspozycjỉ ${ }^{3}$. Zmiany te są postrzegane jako pociemnienia, pojaśnienia, zmiany kąta odcienia bądź zbielenia ${ }^{4}$. Do ustalenia kierunku zmian w badanym obrazie konieczne było rozpoznanie jego budowy technicznej i zidentyfikowanie użytych materiałów, a następnie wykonanie próbek warstw malarskich zawierających zidentyfikowane pigmenty i spoiwa jako podstawy dalszych badań. Istotne było także określenie stanu zachowania oraz przyczyn dotychczasowych zniszczeń.

\section{Cel i przedmiot badań}

Badaniami objęto warstwy malarskie, do których użyto farb sporządzonych własnoręcznie z wykorzystaniem pigmentów wykonanych według starych

3 Usystematyzowanie kierunków zmian wyglądu kolorystyki wraz z przyczynami ich wystąpienia zob. Elżbieta Szmit-Naud, Uzupełnienia ubytków warstwy malarskiej obrazów. Zmiany optyczne a stabilność stosowanych materiałów (Toruń: Wydawnictwo UMK, 2006), 109-138.

4 Szmit-Naud, Uzupełnienia, 109, 113, 116, 129, 131. 
receptur oraz pigmentów historycznych firmy KREMER ${ }^{5}$. Doboru pigmentów dokonano na podstawie wyników badań obrazu Ukrzyżowanie. Ze zidentyfikowanych w oryginalnej warstwie malarskiej pigmentów wybrano biel ołowiową, żółcień cynowo-ołowiową, czerwień żelazową, minię, cynober, azuryt naturalny gruboziarnisty oraz drobnoziarnisty, malachit, czerń kostną, oraz czerwień organiczną - kraplak. Zdecydowano się także na dołączenie ultramaryny oraz indygo, które zidentyfikowano w warstwach wtórnych. Zestawienie użytych pigmentów zawiera tabela 1 . Farby sporządzono rozcierając kolejne pigmenty z dwoma wybranymi spoiwami, które były stosowane w XVI wieku, tj. olejnym oraz temperowym ${ }^{6}$. Wykonano także odrębne warstwy $\mathrm{z}$ wymienionych spoiw w celu określenia zmian wyglądu spoiwa w procesie starzenia. Założono, że dołączenie tych warstw do badanego zestawu może wspomóc interpretację zmian wyglądu poddanych starzeniu warstw malarskich zawierających wybrane pigmenty.

5 Farby wykonała Monika Kęsy. Pigmenty zostały udostępnione dzięki uprzejmości p. Marcina Figurskiego - autora oraz producenta pigmentów według dawnych receptur. Ultramarynę wykonano według przepisu Cenniniego Cennini, zob. Cennino Cennini, Rzecz o malarstwie (Florencja: Florencka Oficyna Tyszkiewiczów, 1933), 33-35. Pozostałe minerały, czyli azuryt, malachit oraz cynober, były rozkruszane w spiżowym moździerzu, ucierane na kamiennej płycie z wodą, a następnie płukane wodą i suszone. Uzyskano dwie frakcje azurytu: gruby i bardziej zmielony. Kraplak z korzenia marzanny farbiarskiej (Rubia tinctorium $L$ ) gotowano $\mathrm{z}$ ałunem glinowo-potasowym $\mathrm{KA} 1\left(\mathrm{SO}_{4}\right)_{2} \cdot 12 \mathrm{H}_{2} \mathrm{O}$, do którego dodano węglan potasu - potaż, w ten sposób otrzymano kraplak osadzony na wodorotlenku glinu $\mathrm{Al}(\mathrm{OH}) 3$; za: Zbigniew Brochwicz, „Interpretacja siarczanu ołowiowego PbSO4 w trakcie identyfikacji barwników organicznych w zabytkowych obiektach polichromowanych", Materiały Muzeum Budownictwa Ludowego w Sanoku 23 (1977): 44-45; Małgorzata Górzyńska i Justyna Olszewska-Świetlik, „Wybrane żółte laki: rekonstrukcja technologiczna”, Biuletyn Informacyjny Konserwatorów Dzieł Sztuki 13, no. 1-2 (2002): 26-33. Biel ołowiową wykonano według receptury zwanej holenderską: płytki ołowiu umieszczono w glinianym naczyniu zawierającym na dnie kwas octowy - ocet winny; przy odpowiedniej temperaturze i wilgotności na płytkach wytworzył się biały osad bieli ołowiowej, który zeskrobywano i płukano. Najstarszy sposób opisał Teofrast z Eressos, później m.in. Teofil Prezbiter, Diversarum Artium Schedula. Średniowieczny zbiór przepisów o sztukach rozmaitych, tłum. Stanisław Kobielus (Kraków: Wydawnictwo Benedyktynów Tyniec, 1998), par. 37, 28; Piotr Rudniewski, Pigmenty i ich identyfikacja (Warszawa: ASP, 1994), 34-35; zob. także Clifford Dyer Holley, The Lead and Zinc Pigments (New York: John Wiley\&Sons, 1909), 2. Sposób produkcji pigmentów być może miał wpływ na charakter uzyskanych warstw malarskich i ich późniejszych zmian. Paleta barw została rozszerzona o pigmenty historyczne firmy KREMER (Kremer Pigmente, Niemcy), ponieważ tych pigmentów nie przygotowano własnoręcznie; są to: czerwień żelazowa, minia, cynober, żółcień cynowo-ołowiowa, indygo oraz czerń kostna.

6 Spoiwo olejne stanowił pokost lniany, na który składało się 100 cz. obj. oleju oraz 3 cz. obj. glejty pełniącej funkcję sykatywującą. Spoiwo temperowe wykonano z 1 żółtka, 1/4 obj. oleju lnianego rozjaśnionego na słońcu oraz dodatku 1/2 objętości octu winnego po uprzednim wytrząśnięciu oleju z żółtkiem. 
Tabela 1. Wykaz pigmentów użytych do badań

\begin{tabular}{|c|c|c|c|}
\hline Lp. $^{*}$ & Nazwa pigmentu & Numer handlowy & Charakterystyka* $^{* *}$ \\
\hline 1 & $\begin{array}{l}\text { Azuryt naturalny } \\
\text { gruboziarnisty }\end{array}$ & $\begin{array}{l}\text { otrzymany według } \\
\text { dawnych receptur }\end{array}$ & rozdrobniony minerał - azuryt naturalny \\
\hline II & $\begin{array}{l}\text { Azuryt naturalny } \\
\text { drobnoziarnisty }\end{array}$ & $\begin{array}{l}\text { otrzymany według } \\
\text { dawnych receptur }\end{array}$ & rozdrobniony minerał - azuryt naturalny \\
\hline III & Minia & 42500 & minia, zawiera ołów $\mathrm{Pb}_{3} \mathrm{O}_{4}$ \\
\hline IV & Cynober & 10620 & cynober mineralny, chiński \\
\hline V & Kraplak & $\begin{array}{l}\text { otrzymany według } \\
\text { dawnych receptur }\end{array}$ & $\begin{array}{l}\text { kraplak (z korzenia marzanny farbiarskiej } \\
\text { Rubia tinctorium L.) strącany potażem }{ }^{*+*}\end{array}$ \\
\hline $\mathrm{VI}$ & $\begin{array}{l}\text { Czerwień } \\
\text { żelazowa }\end{array}$ & 48600 & $\begin{array}{l}\text { czerwień żelazowa naturalna, hematyt, } \\
\text { niezbyt drobno mielona, do malowideł } \\
\text { ściennych, PR/102 }\end{array}$ \\
\hline VII & $\begin{array}{l}\text { Żółcień } \\
\text { cynowo-ołowiowa }\end{array}$ & 10100 & żółcień cynowo-ołowiowa, odcień jasny \\
\hline VIII & Malachit & $\begin{array}{l}\text { otrzymany według } \\
\text { dawnych receptur }\end{array}$ & rozdrobniony minerał - malachit \\
\hline IX & Indygo & 36000 & $\begin{array}{l}\text { indygo oryginalne indyjskie, błękit, pochodzi } \\
\text { z liści rośliny indigofera, w odróżnieniu od } \\
\text { indygo europejskiego z urzetu }\end{array}$ \\
\hline$x$ & Czerń kostna & 47100 & czerń kostna, PBK 9 \\
\hline$X I$ & Biel ołowiowa & $\begin{array}{l}\text { otrzymany według } \\
\text { dawnych receptur }\end{array}$ & biel ołowiowa \\
\hline XIII & $\begin{array}{l}\text { Ultramaryna } \\
\text { naturalna }\end{array}$ & $\begin{array}{l}\text { otrzymany według } \\
\text { dawnych receptur }\end{array}$ & rozdrobniony minerał - lapis lazuli \\
\hline
\end{tabular}

Numeracja jest zgodna z numeracją zestawów próbek na kartonikach przedstawionych na il. 1. Numer XII oraz XVI to czyste spoiwa. Numer XIV: Czerwień oraz XV: Błękit stanowią 5-warstwowe rekonstrukcje malarskie wykonane na podstawie badań. Dla obu zestawów: 1 - zaprawa kredowo-klejowa; 2 - izolacja olejna; 3 - podmalowanie (XIV: cynober, żółcień cynowo-ołowiowa, czerń kostna, minia; XV: azuryt gruboziarnisty i drobnoziarnisty); 4 - warstwa malarska (XIV: minia, czerwień żelazowa; XV: ultramaryna); 5 - laserunek (XIV: kraplak; XV: indygo).

*** Charakterystyka pigmentów według katalogu pigmentów dostępnego na oficjalnej polskiej stronie firmy KREMER: „Kremer Polska” (dostęp August 16, 2017), http://kremerpolska. $\mathrm{com} / \mathrm{katalog} /$.

*as Potaż (ług drzewny) to węglan potasu zanieczyszczony węglanem sodu (ok. 6\%), siarczanem potasu (ok. 25\%) oraz chlorkiem potasowym (ok. 7\%), za: Justyna Olszewska-Świetlik i Zuzanna Rozłucka, „Badania czerwonych laserunków metodą mikroskopii fluorescencyjnej UV", Acta Universitatis Nicolai Copernici. Zabytkoznawstwo i Konserwatorstwo 34 (2005): 143. 


\section{Wykonanie badań}

Przygotowane farby zostały użyte do naniesienia na bezkwasową tekturę warstw malarskich w postaci poziomych pasów ${ }^{7}$. Farbę położono za pomocą szpatułki w celu uzyskania możliwie gładkiej powierzchni. Każda farba z tej grupy została także użyta w rozbiale, z dodatkiem bieli ołowiowej, której ilość była uwarunkowana osiągnięciem przez barwną powierzchnię współczynnika odbicia (R) rzędu 30-40\% ${ }^{8}$. Próbki sezonowano przez trzy miesiące. $\mathrm{W}$ ramach badań wykonano również próby układu warstw wybranych partii barwnych w pełnym tonie, tj. czerwonego płaszcza Jana Ewangelisty oraz błękitnego płaszcza Marii. Na dwa zaizolowane podłoża naniesiono po dwie warstwy zaprawy kredowo-klejowej, którą po wyschnięciu wyszlifowano

7 W badaniach wybranych warstw malarskich, chcąc ograniczyć wpływ starzenia się innych elementów na ich rezultaty, zastosowano tekturę bezkwasową, która jest bardziej odporna na działanie UV od podłoża zastosowanego w obrazie. W trakcie eksperymentu okazało się, że tektura jest mocno nasycona klejami, które fluoryzowały na niebiesko w promieniowaniu UV, zakłócając czytelność pozostałych zjawisk fluorescencji w badanych przekrojach poprzecznych próbek - a tym samym nie spełniła oczekiwań. W kolejnych badaniach należałoby wybrać inne podłoże, np. niefluoryzujący i nieabsorbujący materiał. Tektura została uprzednio zaizolowana 6-proc. roztworem wodnym żelatyny.

8 Zastosowanie rozbiału farb pozwala na prawidłową ocenę ich trwałości dzięki zwiększeniu odbicia światła w warstwie. Porównanie wyników badań warstw malarskich uzyskanych z farb w pełnym tonie i rozjaśnionych może wykazywać duże rozbieżności, za: Elżbieta Szmit-Naud, „Rozpuszczalnikowe farby przeznaczone do uzupełnień ubytków warstwy malarskiej - właściwości aplikacyjne i stabilność w procesie starzenia”, w Badania technologii i technik malarskich, konserwacja dzieł sztuki, kopia. Księga pamiątkowa z okazji jubileuszu 50-lecia pracy dedykowana prof. dr. art. kons. Józefowi Flikowi, red. Justyna Olszewska-Świetlik, (Toruń: Wydawnictwo UMK, 2007), 303; Elżbieta Szmit-Naud, „Farby dla konserwatorów malarstwa - właściwości aplikacyjne i stabilność", Ochrona Zabytków 3 (2007): 61-62. Odzwierciedla to zasadę - wskazywaną przez innych autorów i obowiązującą w normach że w wymalowaniach największe zmiany barwy ( $\mathrm{dE}^{*}$ ) występują w warstwach, których krzywe odbicia osiągają ok. 40\% odbicia w maksimum absorpcji (minimum odbicia) na krzywej odbicia tej warstwy, za: Ruth Johnston-Feller et al., „The Kinetics of Fading: Opaque Paint Films Pigmented with Alizarin Lake and Titanium Dioxide", Journal of the American Institute for Conservation 23, no. 2 (1984): 126; norma ASTM Test Methods for Lightfastness of Pigments Used in Artists' Paints (D 4303), Test Method A, za: „Product Information Sheet”, Golden Artist Colors (dostęp October 27, 2017), https://www.goldenpaints.com/technicalinfo_msapaint. W celu ustalenia prawidłowego rozbiału wykonano próbki malarskie z farb zawierających pigment w pełnym tonie w spoiwie olejnym oraz próbki z pigmentem, które stopniowo rozbielano. Następnie wykonano pomiary instrumentalne każdej z nich, by określić, jaki dodatek pozwala uzyskać odbicie w minimum odbicia zgodne z wymogami. Próbki wykonane w pełnym tonie posłużyły później jako wzorcowe. 
przy użyciu papierów ściernycḥ. Po nałożeniu zaprawy sezonowano podłoża przez trzy miesiące $w$ temperaturze pokojowej i wilgotności względnej 30-40\%. Następnie zaizolowano zaprawę klejem glutynowym ${ }^{10}$. Na tak przygotowanym podłożu wykonano rysunek czernią kostną w spoiwie temperowym przy użyciu okrągłego pędzla ${ }^{11}$. Po wyschnięciu rysunku odpowiednio mniejszą powierzchnię zaizolowano pokostem lnianym. Na wyschniętą izolację naniesiono schodkowo barwne mieszaniny, nawarstwiając je kolejno, po odpowiednim wyschnięciu warstwy poprzedniej, imitując układ warstw stosowany w technice wielowarstwowej. Po nałożeniu trzech warstw próbki malarskie sezonowano w tych samych warunkach przez trzy miesiące. Wykonano także próbki wybranych spoiw, nakładając ich warstwy na to samo tekturowe, bezkwasowe podłoże oraz na uprzednio odtłuszczone podłoże szklane. Próbki na tekturze sezonowano przez trzy miesiące, natomiast na szklanym podłożu przez miesiąc w tych samych warunkach. Przygotowane zestawy przedstawiono na il. 2.

Wszystkie wykonane próbki poddano procesowi przyspieszonego starzenia pod wpływem światła. W tym celu umieszczono je w aparacie Xenotest ${ }^{\circledR}$ Alpha HE (Atlas, USA), gdzie źródłem światła jest lampa ksenonowa o dostosowanym zakresie widmowym obejmującym bliski ultrafiolet i promieniowanie widzialne. Warunki starzeniowe imitowały warunki we wnętrzach pomieszczeń ${ }^{12}$, przy wilgotności względnej utrzymywanej na poziomie $60 \%$. Temperatura na próbkach nie przekraczała $30^{\circ} \mathrm{C}$. W procesie starzenia zastosowano tryb z obrotem próbek wokół własnej osi. Próbki były postarzane jednocześnie z niebieskim standardem o znanej odporności (ISO 105) ${ }^{13}$, dzięki temu kontrolowano proces, przeprowadzony w pięciu etapach. Starzenie zakończono, gdy wzorzec siódmy skali niebieskiej zmienił się w stopniu

9 Zastosowano to samo podłoże i przeklejenie jak w zestawach wyżej opisanych. Do wykonania zaprawy posłużono się 8-proc. roztworem wodnym żelatyny, który wymieszano z kredą szampańską. Przy szlifowaniu posłużono się papierami ściernymi o gramaturze 400 i 800.

10 Jako przeklejenie posłużył 6-proc. roztwór wodny żelatyny.

11 Wykorzystano to samo spoiwo temperowe i olejne. Zob. przypis 6.

12 Tzw. światło zza szyby. Promieniowanie z rejonu 300-320 nm zostało wyeliminowane przez filtr Xenochrome 320, spektrum iluminatora zawierało się w przedziale 320-700 nm.

13 BWS (Blue Wool Standard) - 8-stopniowa skala niebieska przeznaczona do badania odporności barw w przemyśle tekstylnym, standardowo stosowana też do oceny zmian barw innych materiałów, np. pigmentów. Za: Elżbieta Szmit-Naud, „Wrażenie barwy i klasyfikacja barw. Ocena zmian barwy materiałów stosowanych w konserwacji dzieł sztuki”, Acta Universitatis Nicolai Copernici. Zabytkoznawstwo i Konserwatorstwo 34 (2005): 54. 
czwartym szarej skali kontrastu (ISO 105 A02) ${ }^{14}$. Próbki otrzymały dawkę promieniowania równą $69746 \mathrm{~kJ} / \mathrm{m}^{2}$, mierzoną w zakresie bliskiego ultrafioletu $(320-400 \mathrm{~nm})^{15}$.

\section{Metodyka badań}

Trwałość warstw malarskich analizowano pod kątem stanu zachowania obrazu, określonego na podstawie wyników badań jego techniki i technologii ${ }^{16}$. Podjęto także próbę określenia zmian niektórych komponentów. W tym celu obserwowano kierunek zmian wyglądu na każdym etapie starzenia, rejestrowanym fotograficznie ${ }^{17}$. Do ustalenia kierunku zmian wykorzystano także pomiary sferycznym spektrofotometrem SP-64 X-Rite (USA) wykonane przed i po starzeniu w tych samych, oznaczonych miejscach ${ }^{18}$; na tej podstawie wyznaczono różnicę całkowitą barwy $\Delta \mathrm{E}^{* 19}$.

Bezpośrednio przed rozpoczęciem sztucznego starzenia próbek oraz przed przeprowadzeniem pomiarów po jego zakończeniu wykonano zdjęcia

14 Opis stopni kontrastów skali szarej zob. Szmit-Naud, „Wrażenie barwy”, 57.

15 Takie promieniowanie imituje warunki „światła zza szyby”, za: Elżbieta Szmit-Naud, „Uzupełnienia ubytków warstwy malarskiej obrazów - badania materiałów stosowanych współcześnie”, Acta Universitatis Nicolai Copernici. Zabytkoznawstwo i Konserwatorstwo 34 (2005): 94.

16 Zob. przypis 2.

17 Fotografie w świetle widzialnym (dziennym, rozproszonym) w trakcie kontroli między kolejnymi etapami starzenia oraz po jego zakończeniu wykonała Monika Kęsy aparatem Nikon D7000.

18 Badania barwometryczne powierzchni próbek przeprowadziła Elżbieta Szmit-Naud z Zakładu Konserwacji Malarstwa i Rzeźby Polichromowanej. Pomiary wykonano w standardowych warunkach, przy kącie obserwacji $10^{\circ}$ (jest to tzw. obserwator dodatkowy CIE 1964 $10^{\circ}$ ) i w promieniowaniu iluminantu CIE $\mathrm{D}_{65}$, którego rozkład widmowy mocy odpowiada rozkładowi mocy uśrednionego światła dziennego w różnych warunkach dnia przy różnym zachmurzeniu oraz na różnej szerokości geograficznej krajów europejskich, spektrum 400-700 nm, z włączoną składową zwierciadlaną (SCI). Aparatura jest wyposażona w kulę Ulbrighta, co pozwala na oświetlenie próbek światłem rozproszonym, umożliwiające równomierne odbicie od nieregularnych powierzchni (np. azurytu gruboziarnistego). Dane rejestrowano w przestrzeni CIELAB 1976 - zob. Szmit-Naud, „Wrażenie barwy”, 49, 54, 58-59; Szmit-Naud, „Rozpuszczalnikowe farby”, 304.

$19 \Delta \mathrm{E}^{*}$ określa liczbowo całkowitą różnicę między dwiema porównywanymi barwami. Różnica ta jest wyrażona pierwiastkiem sumy kwadratów $\Delta \mathrm{L}^{*}, \Delta \mathrm{a}^{*}, \Delta \mathrm{b}^{*}$. Określona liczbowo wartość zmiany (różnicy) informuje o stabilności barwnej badanego materiału. Za: Szmit-Naud, „Rozpuszczalnikowe farby”, 303; Szmit-Naud, „Wrażenie barwy”, 49, 62. Ze względu na dużą liczbę niskich wartości różnic barwy w porównaniach użyto wzoru będącego modyfikacją wzoru standardowego - zob. Szmit-Naud, „Rozpuszczalnikowe farb”, 304. 
w różnych zakresach promieniowania, tj. VIS, UV, IR oraz IRFC ${ }^{20}$. Po starzeniu sporządzono także zdjęcia mikroskopowe wybranych próbek w promieniowaniu widzialnym oraz we fluorescencji wzbudzonej promieniowaniem UV. Ponadto pobrano próbki z partii starzonych oraz niestarzonych, osadzono je w żywicy i wykonano przekroje poprzeczne. Przekroje sfotografowano w promieniowaniu VIS oraz we fluorescencji wzbudzanej promieniowaniem UV. Następnie przeprowadzono analizę porównawczą wyglądu przekrojów poprzecznych próbek partii starzonych oraz niestarzonych zarejestrowanych na fotografiach ${ }^{21}$.

\section{Ocena wizualna zmian wyglądu}

W ramach oceny wizualnej dokonano analizy porównawczej wyglądu poszczególnych zestawów próbek przed i po starzeniu pod wpływem promieniowania widzialnego (VIS), a także zmian ich fluorescencji wzbudzonej promieniowaniem UV. Wizualnej ocenie podlegały również zmiany, jakie zarejestrowano na zdjęciach zestawów próbek wykonanych w bliskiej podczerwieni (IR) oraz w technice tzw. fałszywych kolorów (IRFC). Przeprowadzono też analizę porównawczą wyglądu przekrojów poprzecznych próbek starzonych i niestarzonych metodą mikroskopii standardowej VIS oraz fluorescencyjnej UV.

\section{Instrumentalna ocena zmian barwy}

Ponieważ ocena wizualna nie pozwala precyzyjnie określić, na czym polega dostrzegalna zmiana barwy próbek przed i po przyspieszonym starzeniu, wykorzystano do tego celu ocenę barwometryczną. Uzyskane dane wska-

20 Fotografie w promieniowaniu VIS, UV oraz IR (w tym IRFC) zestawów przed i po starzeniu wykonał Adam Cupa z Zakładu Technik i Technologii Malarskich IZK UMK. Badania fluorescencji wzbudzonej UV, zdjęcia w zakresie widzialnym, obrazy w tzw. technice fałszywych kolorów oraz reflektografię w bliskiej podczerwieni do $1000 \mathrm{~nm}$ wykonano aparatem FUJIFILM X-T1 IR. Użyte filtry: przepuszczający promieniowanie UV (300-400 nm) filtr odcinający UV i VIS, filtr odcinający UV oraz filtry do podczerwieni przepuszczające promieniowanie powyżej 780, 840 i $900 \mathrm{~nm}$. Zastosowano oświetlenie halogenowe oraz UV typu Blacklight Blue z maximum linii $365 \mathrm{~nm}$.

${ }^{21}$ Zdjęcia mikroskopowe w zakresie promieniowania VIS i UV wykonała Monika Kęsy. Posłużono się mikroskopem UV/VIS Nikon Eclipse CI ze źródłem światła z palnika rtęciowego HBO Osram i lampy halogenowej przy powiększeniu x20. Obraz zarejestrowano aparatem Canon 1000D. Próbki zostały osadzone w żywicy „Duracryl Plus” (prod. Spofa-Dental, Praga) i następnie wyszlifowane przy użyciu papierów ściernych o gramaturze od 300 do 2000. 
zują, jaki parametr się zmienił, tj. czy nastąpił spadek, czy wzrost jasności ${ }^{22}$ oraz nasycenia ${ }^{23}$, a także jaki jest kierunek zmian, gdy dana barwa zmieniła odcień ${ }^{24}$ (np. stała się bardziej żółta). Zmiany $\Delta \mathrm{E}_{\text {ab }}^{*}$ poszczególnych próbek zostały przedstawione na wykresie 1 , natomiast zmiany obliczone według wzoru $\Delta$ E2000 ukazuje wykres 2 (ze względu na dużą rozpiętość różnic uznano za zasadne przedstawienie wyników uzyskanych według obu wzorów).

Omawiając rezultaty odnoszono się najczęściej do wartości zmian obliczonych według wzoru $\Delta$ E2000, uznawanego za trafniej odzwierciedlający różnice barwy, jeśli są one niewielkie $\left(\Delta \mathrm{E}^{*}{ }_{\mathrm{ab}}<5\right)$. W pozostałych przypadkach rozpatrywano dane otrzymane przy użyciu podstawowej formuły (tj. $\Delta \mathrm{E}^{*}{ }_{a b}$, gdy $\geqslant 5$ ). Analizowano także zmiany przebiegu krzywych odbicia próbek przed i po starzeniu.

\section{Wyniki badań}

Najbardziej zauważalną zmianę powstałą w wyniku sztucznego starzenia odnotowano w zestawie V - w kraplaku. Ten organiczny pigment wykazał najniższą stabilność niezależnie od użytego spoiwa. Zmiany warstwy ze spoiwem temperowym są jednolite na całej eksponowanej powierzchni prób$\mathrm{ki}$, natomiast na powierzchni kraplaku w spoiwie olejnym w pełnym tonie pojawił się także biały nalot. Nalot ten, w zakresie promieniowania UV, na przekroju próbki V.3 odznacza się jasną fluorescencją ${ }^{25}$ (il. 3). Różnica zmian barwy tych warstw jest ogromna i wynosi $\Delta \mathrm{E}^{*}{ }_{\mathrm{ab}}=37,83$ dla spoiwa temperowego oraz dla olejnego $\Delta \mathrm{E}^{*}{ }_{\mathrm{ab}}=27,44$. Zmiany dla rozbiału są mniejsze, lecz wciąż bardzo duże i wynoszą $\Delta \mathrm{E}^{*}{ }_{\mathrm{ab}}=17,14$ dla warstwy olejnej i $\Delta \mathrm{E}^{*}{ }_{\mathrm{ab}}=13,41$ dla temperowej. Tak duże zmiany sprawiają, że dana barwa badanej warstwy przed i po starzeniu, jest postrzegana jako dwie różne barwy o zupełnie innym odcieniu i jasności.

${ }^{22}$ Jasność - określa, na ile dana barwa zbliża się do bieli (100) lub czerni (0); w układzie CIE oznaczana jako L*. Za: Szmit-Naud, „Wrażenie barwy”, 42, 49.

${ }^{23}$ Nasycenie (chroma) - określa czystość barwy, którą definiuje zawartość bieli lub czerni; w układzie CIE oznaczana jako C*. Za: Szmit-Naud, „Wrażenie barwy”, 42, 49.

24 Odcień - określa go długość fali elektromagnetycznej w zakresie promieniowania widzialnego - informuje np., czy barwa jest czerwona, żółta, zielona, czy niebieska; w układzie CIE oznaczany jako h*. Za: Szmit-Naud, „Wrażenie barwy”, 42, 49.

25 Za fluorescencję kraplaku odpowiedzialna jest prawdopodobnie purpuryna - tworzy ona chelaty z metalami pochodzącymi z substratów, na których są osadzane barwniki, np. $\mathrm{Al}(\mathrm{OH})_{3}$, mające zdolność fluorescencji; za: E. René de la Rie, "Fluorescence of Paint and Varnish Layers” (Part I, II, III), Studies in Conservation 27, no. 1, 2, 3 (1982), tu (Part I), 5. 
$\mathrm{Z}$ analizy pomiarów barwy wynika, że zmiany, jakie zaszły pod wpływem starzenia, w większości badanych warstw malarskich dotyczą głównie wzrostu jasności oraz spadku nasycenia. Wyraźne odstępstwo stanowi cynober (zestaw IV), w którego pełnym tonie, zarówno w spoiwie temperowym, jak i olejnym, stwierdzono znaczne pociemnienie (próbka IV.1 - spadek jasności o 5,9; IV.3 - spadek jasności o 3,69). Pociemnienie cynobru było już zauważalne po drugim etapie starzenia i było większe w warstwie ze spoiwem temperowym. We wszystkich warstwach z cynobrem zarejestrowano także wyraźny spadek nasycenia barwy. Rozbiał z użyciem cynobru, który miał ciepły odcień, po starzeniu wydaje się wręcz siny. Zmiany te można zaobserwować na il. 4. Nieznacznie pociemniały jeszcze dwa inne pigmenty: minia w spoiwie olejnym (próbka III. $3-\Delta \mathrm{L}^{*}=1,31$ ) oraz rozbiał malachitu w spoiwie temperowym (próbka VIII. $2-\Delta \mathrm{L}^{*}=2,33$ ).

Największy wzrost jasności zarejestrowano w warstwie z kraplakiem, która - jak wcześniej podano - jednocześnie wykazała najwyższą zmianę barwy. Różnica jasności wynosiła aż 28,97 dla spoiwa temperowego oraz 26,42 dla tempery. W rozbiale temperowym kraplaku, który szybciej wykazywał zmiany (już po pierwszym etapie starzenia), w efekcie końcowym zarejestrowano niższą wartość zmiany barwy $\left(\Delta \mathrm{E}^{*}\right.$ ab dla V.2 - 13,41; V.4-17,14) niż w pełnym tonie $\left(\Delta \mathrm{E}^{*}{ }_{\mathrm{ab}}\right.$ dla V.1 - 37,83; V.3 - 27,44). W warstwach malarskich zawierających naturalne minerały, tj. azuryt (zestaw I, II), malachit (zestaw VIII) oraz ultramarynę (zestaw XIII), najmniej stabilny okazał się ten ostatni. Zmiany barwy ultramaryny są znaczniejsze w pełnym tonie $\left(\Delta \mathrm{E}^{*}\right.$ ab wynosi 8,64 dla spoiwa olejnego i 8,23 dla tempery). Wpływ na to miała głównie zmiana nasycenia, a w przypadku warstwy olejnej - także, w większym stopniu, jasności. W warstwie olejnej zarejestrowano znaczny wzrost nasycenia z pojaśnieniem, przy nieznacznej zmianie kąta odcienia. W warstwie z temperą wykazano, odwrotnie niż w oleju, spadek jasności oraz znaczną zmianę kąta odcienia w kierunku bardziej żółtego, przy jednoczesnym znacznym spadku nasycenia. Zmiany ilustruje przebieg krzywej odbicia warstw niestarzonych i starzonych (il. 5). Badanie warstw zawierających azuryt o dużym i drobnym ziarnie (zestaw I, II) wykazuje, że pigment o większej frakcji (zestaw I) wykazał się większą odpornością; także w jego rozbiałach zarejestrowano mniejszą różnicę barwy niż w rozbiałach azurytu z drobną cząsteczką, a wartość zarejestrowanej zmiany wyrażonej przez $\Delta \mathrm{E}_{00}$ mieściła się między 1 a 2 . Najmniejszą stabilnością wykazał się rozbiał drobnego azurytu w spoiwie olejnym, gdzie różnica barwy $\Delta \mathrm{E}^{*}{ }_{\text {ab }}$ wyniosła aż 7,22, podczas gdy w spoiwie temperowym $\Delta \mathrm{E}_{00}=2,38$. 
W zestawach próbek zawierających pigmenty na bazie naturalnych minerałów i przechowywanych po starzeniu przez dwa miesiące bez dostępu światła odnotowano cofanie się zmian, wywołanych najprawdopodobniej przez zmiany barwy spoiwa. Z oceny wizualnej wynika, że zarówno warstwy malarskie zawierające olej, jak i - w większym stopniu - temperę przybierały wygląd bardziej żółty i ciemniejszy po przechowywaniu ich w ciemności. Widać to dobrze na przykładzie ultramaryny, która w spoiwie temperowym, po przechowywaniu bez dostępu światła, w części eksponowanej jest ciemniejsza niż w miejscu nieeksponowanym podczas starzenia (il. 5).

Znaczne różnice barwy zarejestrowano dla kryjących warstw zawierających indygo (zestaw IX). Zmiany dotyczą głównie wzrostu jasności: w pełnym tonie jest on mniejszy niż w partiach rozbielonych. W rozbielonej warstwie temperowej różnica jasności wynosi aż 14,2. Znacznie mniej stabilny okazał się laserunek wykonany na bazie indygo (próbka XV.5).

Warstwy malarskie z żółcienią cynowo-ołowiową (zestaw VII) charakteryzują bardzo nieznaczne różnice jasności (nieprzekraczające 0,5) i istotna różnica nasycenia: jego spadek wahał się od 3,32 dla rozbiału w spoiwie olejnym do 5,43 dla warstwy w pełnym tonie w tym spoiwie. Barwa w efekcie tych zmian jest mniej czysta i intensywna w porównaniu ze stanem sprzed starzenia. Całkowita różnica barwy $\Delta \mathrm{E}^{*}{ }_{\text {ab }}$ warstw z tym pigmentem w pełnym tonie ze spoiwem temperowym przekroczyła 5,01 , z olejnym 5,25 , natomiast w warstwach rozbielonych zarówno ze spoiwem temperowym, jak i olejnym przyjęła niższe wartości - $\Delta \mathrm{E}_{00}$ wyniosło odpowiednio 2,15 i 2,41.

Różnica barwy warstw zawierających czerwień żelazową (zestaw VI) polegała na niewielkim spadku jasności, przy znacznym spadku nasycenia farby temperowej w pełnym tonie $\left(\Delta C^{*}=4,85\right)$ oraz nieznacznym pojaśnieniu jej rozbiału przy jednoczesnym spadku nasycenia. Farba olejna w pełnym tonie nieznacznie pojaśniała i nastąpił wzrost nasycenia o 0,71. Najbardziej pojaśniał rozbiał olejny, bo o ponad trzy jednostki, i spadło jego nasycenie o 1,63.

Czerń w spoiwie zarówno olejnym, jak i temperowym (zestaw X) w pełnym tonie wykazała się dużą stabilnością, a wartość różnicy barwy wyniosła mniej niż jednostkę. W mieszaninie z bielą, niezależnie od użytego spoiwa, jej stabilność w świetle okazała się mniejsza, a całkowita zmiana barwy $\left(\Delta \mathrm{E}_{00}\right)$, która polegała głównie na wzroście jasności, wyniosła 2,26 dla warstwy malarskiej ze spoiwem olejnym oraz 2,18 z temperowym.

Zmiany spoiw można prześledzić także na podstawie ich fluorescencji wzbudzonej w zakresie wzbudzania promieniowaniem UV. Próbki niesta- 
rzone wykazywały silniejszą fluorescencję od wystawionych na działanie światła, które charakteryzował jej spadek oraz zmiana jej odcienia z żółtego w ciemnoniebieski. Dotyczyło to zarówno spoiwa olejnego, temperowego, jak i przeklejenia na bazie kleju glutynowego. Wyjątek stanowią warstwy zawierające pigmenty otrzymywane z barwników naturalnych, tj. kraplak (zestaw V i próbka XIV.5) oraz indygo (zestaw IX i próbka XV.5) (il. 6).

Jeśli chodzi o zmiany na zestawach malarskich (zestaw XIV, XV), w większości pokrywają się one ze zmianami w obrębie warstw zawierających pojedyncze pigmenty. Różnica barwy zaprawy i izolacji przed i po starzeniu nie była znaczna. Dla izolacji był to niewielki wzrost jasności spowodowany pojaśnieniem spoiwa olejnego. W obrębie brązowej warstwy podmalowania z zestawu XIV nastąpił, z powodu zawartości cynobru, znaczny spadek nasycenia barwy, którego różnica przed i po starzeniu wyniosła ponad dziesięć jednostek. Zmiana ta miała wpływ także na wygląd kolejnej badanej strefy ze znajdującą się na niej warstwą czerwieni (próbka XIV.4). W warstwie zawierającej stabilną - jak wykazało badanie - czerwień żelazową oraz dość odporną minię zarejestrowano znaczny spadek nasycenia pod wpływem zmian warstwy spodniej. Ostatnia strefa próbki (tj. zawierająca pełen układ warstw), z laserunkiem na bazie kraplaku (XIV.5), bardzo pojaśniała, a różnica jasności wyniosła aż 12,02. Jednocześnie nastąpił spadek jej nasycenia, na który wpływ miały także spodnie warstwy. Podobnie jak na próbce V.3, na powierzchni laserunku pod wpływem światła pojawił się biały nalot, który wykazuje jasną fluorescencję w promieniowaniu UV (il. 7).

W zestawie XV w warstwie azurytu (próbka XV.3) za różnicę barwy $\Delta \mathrm{E}^{*}{ }_{a b}$ wynoszącą 6,86 odpowiedzialna jest przede wszystkim znaczna zmiana kąta odcienia - o około $30^{\circ} \mathrm{w}$ kierunku żółtym - oraz spadek jasności o prawie dwie jednostki. Warstwy z ultramaryną (próbka XV.4) oraz indygo (próbka XV.5), podobnie jak z azurytem, pożółkły, co jest widoczne w zmianie ich kąta odcienia. Wzrost nasycenia zarejestrowany w warstwie zawierającej indygo może mieć związek z utratą siły krycia laserunku i odsłonięciem warstwy spodniej o wyższym nasyceniu. W tym zestawie zarejestrowano także największe cofnięcie się zmian, najwyraźniej powodowane zmianami barwy dotyczącymi oleju (il. 8). Przy porównaniu wyglądu próbek zestawu zaraz po zakończeniu procesu sztucznego starzenia i tego samego zestawu trzymanego bez dostępu światła przez dwa miesiące po starzeniu można stwierdzić powtórne żółknięcie oleju. Wygląd tego zestawu po okresie tych dwóch miesięcy znacznie się różni od jego wyglądu zaraz po starzeniu, gdzie olej nie był tak pożółkły (il. 8). 
Porównanie reflektogramów badanych próbek w bliskiej podczerwieni, wykonanych przed i po starzeniu, potwierdza opisane zmiany, choć kontrast widoczny na reflektogramach jest mniejszy. Dla większości warstw kierunek zmian jasności zarejestrowany w zakresie wzbudzania światłem widzialnym (VIS) VIS i zauważalny na reflektogramach jest ten sam. Wyjątkiem jest warstwa temperowa zawierająca ultramarynę (próbka XIII.1), która według oceny instrumentalnej nieznacznie pociemniała, podczas gdy na reflektogramie w podczerwieni zmiana widoczna jest jako pojaśnienie; może to wskazywać, że za pociemnienie warstwy ujawnione w świetle widzialnym VIS odpowiedzialne jest spoiwo. Analiza obrazów zarejestrowanych w tzw. technice fałszywych kolorów pozwala dostrzec zmiany podobne do widocznych w reflektografii w bliskiej podczerwieni. Inaczej przedstawia się sytuacja warstwy z malachitem (zestaw VII), gdzie zmiana w rozbiale tempery zarejestrowana w IRFC jako pojaśnienie, w IR przedstawia się jako pociemnienie. Barwa cynobru (zestaw IV) w kolorowej podczerwieni przed starzeniem jest żółta, po starzeniu ma odcień zgniłozielony, co ma związek z pociemnieniem tego pigmentu pod wpływem światła.

\section{Podsumowanie wyników badań próbek i wnioski}

Objęte badaniami warstwy malarskie uzyskane z farb przygotowanych z pigmentów historycznych w spoiwie temperowym i olejnym wykazały różny stopień odporności na działanie światła. Na zmiany barwy w obrębie warstw malarskich mają wpływ właściwości chemiczne pigmentów, a także rodzaj otaczającego je spoiwa. Zmiany te następują stopniowo i najczęściej dotyczą kąta odcienia (często w nieznacznym stopniu), nasycenia i jasności, a postrzegane są jako pojaśnienia, pociemnienia-poszarzenia, zmiany intensywności barwy (nasycenia), a także zmiany jej odcienia - żółknięcie.

Różnice wyglądu warstw wykonanych farbami ze spoiwem temperowym oraz olejnym przed i po starzeniu w dużej mierze wynikają z zachowania spoiwa przy ekspozycji na działanie światła i przy jej braku. Zarówno pokost, jak i tempera w swoim składzie mają olej, który „bieleje” na słońcu, barwnik żółtka również prawdopodobnie płowieje wystawiony na światło ${ }^{26}$. Spoiwa pod wpływem starzenia pojaśniały, po czym ponownie żółkły podczas prze-

26 David Saunders i Jo Kirby, "Light-Induced Colour Changes in Red and Yellow Lake Pigments", National Gallery Technical Bulletin 15 (1994): 90 (dostęp September 11, 2017) https://www. nationalgallery.org.uk/media/15692/saunders_kirby1994.pdf; Elżbieta Szmit-Naud, "Przy- 
chowywania bez dostępu światła. Większa intensywność tych zmian zauważalna była w warstwach o spoiwie temperowym, co może mieć związek z wytworzeniem barwnych związków w procesie starzenia białek ${ }^{27}$. Zmiany te były dostrzegalne w warstwach zawierających azuryt, czerwień żelazową, malachit oraz ultramarynę. Próbki wystawione na działanie światła charakteryzował spadek zauważalnej intensywności fluorescencji wzbudzonej promieniowaniem UV oraz zmiana jej odcienia z żółtego na ciemnoniebieski ${ }^{28}$. Wyjątek stanowią zestawy zawierające warstwy na bazie pigmentów otrzymanych z barwników organicznych: kraplak (V) oraz indygo (IX), gdzie w każdej warstwie zarejestrowano wzrost fluorescencji na powierzchni próbek - większy dla warstw kraplaku. Warstwy te w pełnym tonie wykazały różową fluorescencję, a w rozbiale jasnożółtą - silniejszą w spoiwie olejnym. Jest to także widoczne na przekrojach poprzecznych próbek z tych warstw. Wzrost fluorescencji spoiwa jest większy we wierzchniej części próbki, co wskazuje, że pod wpływem promieniowania UV zachodzą zmiany przede wszystkim przy powierzchni warstwy. Ziarna pigmentu także charakteryzują się silniejszą fluorescencją po starzeniu.

Ponieważ związki organiczne szybciej ulegają degradacji od nieorganicznych, największe zmiany wykazały warstwy z kraplakiem, które wypłowiały pod wpływem działania światła. Dodatkowym czynnikiem odpowiedzialnym za niską odporność warstw zawierających kraplak jest prawdopodobnie słabe zdyspergowanie pigmentu w spoiwie, co skutkowało utworzeniem chropowatej warstwy z odsłoniętymi cząstkami. Obserwacja próbek w przekroju oraz fotografii mikroskopowych wykazała, jak już nadmieniono, że barwa kraplaku zmieniła się przede wszystkim przy powierzchni, co może być związane z absorpcją krótkich promieni UV, czyli procesem, który zachodzi w najbardziej zewnętrznej części warstwy ${ }^{29}$. Wskazuje to jednoznacznie, że na trwałość barwy warstwy w całym jej przekroju ma wpływ grubość tej warstwy ${ }^{30}$. Wraz

czyny i mechanizmy zmian wyglądu uzupełnień warstw malarskich w obrazach sztalugowych”, Ochrona Zabytków 1-2 (2003): 84.

27 Szmit-Naud, „Przyczyny i mechanizmy”, 84.

28 W wyniku działania światła następuje skrócenie długości fali fluorescencji, a co za tym idzie spadek jej intensywności. Wraz ze skracaniem fal odcień fluorescencji zmienia się z żółtego w kierunku niebieskim; za: De la Rie, „Fluorescence” (Part II), 65-66.

29 De la Rie, „Fluorescence” (Part III), 104.

30 Aviva Burnstock także zwraca uwagę na powierzchniowe działanie promieniowania UV w badanych przez nią przekrojach warstw zawierających czerwień organiczną wyblakła tylko przypowierzchniowa warstwa do grubości $10 \mu \mathrm{m}$, zob. Aviva Burnstock, „The Fading of the Virgin's Robe in Lorenzo Monaco's 'Coronation of the Virgin’”, National Gallery Tech- 
ze wzrostem grubości zwiększa się jej odporność na światło. Z jednej strony przyczynia się do tego ograniczona przenikalność promieniowania UV, z drugiej zaś większa stężenie pigmentu w spoiwie. Warstwy laserunkowe zawierają mniej barwnych cząstek, przy tym są one otoczone większą ilością spoiwa, które przepuszcza większą ilość promieniowania niż warstwy kryją$\mathrm{ce}^{31}$. Kiedy laserunek leży na białym podkładzie, dodatkowo światło, które się od tego podkładu odbija, oddziałuje niekorzystnie na barwne cząstki zawieszone w laserunku ${ }^{32}$. Na warstwie olejnej w pełnym tonie (próbka V.3) oraz na laserunku (próbka XIV.5) pojawił się biały nalot, który trudno jednoznacznie zinterpretować, może być następstwem sposobu otrzymania pigmentu. Zdjęcia mikroskopowe laserunku ukazują, że białe cząstki odpowiadają czerwonym cząstkom w części niestarzonej próbki. Można więc zakładać, że nalot stanowią prawdopodobnie cząstki pigmentu wypłowiałe pod wpływem działania światła. Potwierdzenie tej tezy wymagałoby dodatkowych badań. Nierównomierne zmiany na powierzchni warstwy kraplaku w spoiwie olejnym w pełnym tonie mogą wynikać z ziarnistej powierzchni oraz z nierównej grubości tej warstwy.

W warstwach zawierających cynober odnotowano pociemnienie. Taki wpływ światła na cynober jest dobrze znany, a różnica barwy jest bardziej dostrzegalna w spoiwie temperowym, podobnie jak w wyżej omówionych badaniach $^{33}$. Zmiany te powstają przy jednoczesnej obecności światła oraz jonów chlorkowych (jako zanieczyszczenia) wskutek wytworzenia produktów rozkładu w postaci rtęci metalicznej ${ }^{34}$.

nical Bulletin 12 (1988): 60, (dostęp October 19, 2017) https://www.nationalgallery.org.uk/ upload/pdf/burnstock1988.pdf. D. Saunders i J. Kirby w swoich badaniach dotyczących płowienia barwników organicznych też wspominają o tej zależności, zwracają uwagę, że gęste i dobrze związane warstwy malarskie były odporniejsze od cienkich laserunków, zob. Saunders i Kirby, „Light-Induced”, 89.

31 Inaczej jest, kiedy cząstki barwne absorbują większość padającego promieniowania - wtedy wierzchnia część laserunku będzie szybciej się odbarwiała niż spodnia, ponieważ większość promieniowania będzie już zaabsorbowana przez warstwy wierzchnie. Jest to tzw. efekt filtra; za: Paul M. Whitmore i Catherine Bailie, „Further Studies on Transparent Glaze Fading: Chemical and Appearance Kinetics”, Journal of the American Institute for Conservation 36, no. 3 (1997): 211.

32 Zależność tę podkreśla A. Burnstock, dodając, że uszkodzenie (ścienienie) warstwy laserunku spowoduje zwiększenie tempa zachodzących zmian w warstwie, za: Burnstock, „The Fading”, $61,63$.

33 Rudniewski, Pigmenty, 104.

34 Willemien Anaf, Koen Janssens, i Karolien De Wael, „Formation of Metallic Mercury During Photodegradation / Photodarkening of a-HgS: Electrochemical Evidence”, Angewandte Chemie International Edition 52 (2013): 12570. Zmiany, jakie obserwujemy w zestawie IV, wydają się 
Większą odporność na działanie światła warstw o silniejszym stężeniu cząsteczek barwnych można zaobserwować w warstwach malarskich zawierających indygo (zestaw IX). Pigment ten uchodzi za nieodporny na działanie światła. W grubej, kryjącej warstwie wykazał mniejsze zmiany niż w cienkiej, laserunkowej, która znacznie pojaśniała w spoiwie temperowym (próbka XV.5).

Mało odporna okazała się warstwa zawierająca ultramarynę naturalną (próbki XIII.1 i 3), która w spoiwie temperowym pociemniała, a w olejnym pojaśniała. Zmiany odcienia warstw malarskich z ultramaryną nie są odosobnione, chociaż jest uważana za stabilny pigment. Stwierdzone zostały w badaniach innych farb i polegały częściej na zmianie odcienia, w kierunku bardziej niebieskim ${ }^{35}$. Podobnie jak w opisywanych warstwach malarskich, większe zmiany barwy ultramaryny w większości badanych spoiw zachodziły $\mathrm{w}$ pełnym tonie ${ }^{36}$. Pociemnienie w spoiwie temperowym może być spowodowane wytworzeniem barwnych związków w procesie starzenia białek ${ }^{37}$. $\mathrm{W}$ warstwie z olejem zmiana odcienia mogła się w jakimś stopniu łączyć z jaśniejącym olejem.

Czerwień żelazowa (zestaw VI), która uchodzi za bardzo odporną na działanie światła ${ }^{38}$, w spoiwie olejnym okazała się trwalsza. Pigment ten uznaje się za powstrzymujący degradację tego spoiwa, co omawiane tu obserwacje i wyniki pomiarów barwy mogłyby potwierdzać ${ }^{39}$. Za odnotowane pociemnienie warstwy w spoiwie temperowym, a w istocie jej „poszarzenie” (spadek nasycenia) odpowiedzialne jest prawdopodobnie spoiwo, które w procesie starzenia wytworzyło ciemne związki ${ }^{40}$, podobnie jak w przypadku ultramaryny (próbka III.1).

zachodzić równomiernie na powierzchni warstwy malarskiej, natomiast na przykładzie zilustrowanym w przytoczonym artykule można zauważyć punktowe pojawienie się metalicznej rtęci.

35 Badania farb konserwatorskich zawierających różne spoiwa zob. Elżbieta Szmit-Naud, „Zmiany optyczne retuszy w malarstwie sztalugowym” (rozprawa doktorska, UMK w Toruniu, 2001), 301.

36 Szmit-Naud, „Uzupełnienia ubytków”, 95-96.

37 Szmit-Naud, „Przyczyny i mechanizmy”, 84.

38 Rudniewski, Pigmenty, 102.

39 Zuzanna Rozłucka, Maria Roznerska, i Joanna Arszyńska, Mikroskopia fluorescencyjna (Toruń: Wydawnictwo UMK, 2000), 30.

40 Szmit-Naud, „Przyczyny i mechanizmy”, 84. 
Żółcień cynowo-ołowiowa (zestaw VII), uznawana za odporną na działanie światła ${ }^{41}$, także poszarzała, co wyraża się spadkiem nasycenia barwy zawierających ją warstw (próbki VII.1 i 3). Pozostałe pigmenty wykazały zmiany barwy $\Delta \mathrm{E}^{*}{ }_{\mathrm{ab}}$ oraz $\Delta \mathrm{E}_{00}$ bliskie wartości 2 lub mniej. Najtrwalsze w ekspozycji na działanie światła okazały się warstwy zawierające azuryt gruboziarnisty (zestaw I), czerń kostną (zestaw X), biel ołowiową (zestaw XI) oraz malachit (zestaw VIII), czyli pigmenty, które mają opinię odpornych na operowanie światła ${ }^{42}$.

Zastosowanie azurytu o różnej wielkości cząsteczki pokazuje, że światłotrwałość danego pigmentu maleje wraz ze spadkiem wielkości cząsteczki - na mniejszą cząstkę pigmentu drobnoziarnistego oddziałuje proporcjonalnie większa ilość szkodliwego promieniowania ${ }^{43}$. Obserwacja ta pokrywa się z obiegowymi przekonaniami na temat gorszej jakości drobnych frakcji azurytu, nazywanych „popiołowymi” ${ }^{44}$.

Dodanie bieli do pigmentów barwnych przeważnie sprawia, że światłotrwałość warstw będących takimi mieszaninami maleje. We wszystkich zestawach próbek (z wyjątkiem ultramaryny), niezależnie od użytego spoiwa, pierwsze zmiany, jakie zarejestrowano wzrokowo, dotyczyły rozbiałów. Zastosowana w badaniu biel ołowiowa odbija znaczną ilość promieniowania w zakresie bliskiego ultrafioletu (około 55\%), rozpraszając je w mieszaninie, przez co pojedyncze cząsteczki barwne mogą być w większym stopniu narażone na jego szkodliwe działanie niż w pełnym tonie ${ }^{45}$. Proces ten przebiega zatem zgodnie z przytoczonym stwierdzeniem, że im cząstka barwna jest mniejsza, tym bardziej podlega negatywnemu oddziaływaniu tego promieniowania ${ }^{46}$. Innym czynnikiem wpływającym na pojaśnienie rozbiałów na

41 Rudniewski, Pigmenty, 91.

42 Rudniewski, Pigmenty, 35, 46, 54, 69.

43 Charles H. Giles, David J. Walsh, i Rou S. Sinclair, „The Relation between Light Fastness of Colorants and their Particle Size”, Coloration Technology 93, no. 9 (1977): 348. Zależność tę wskazują także inni autorzy, zob. Burnstock, „The Fading”, 60; Johnston-Feller et al., „The Kinetics", 122.

44 Innym przykładem są badania czerwonych i żółtych laków, które też wykazały podobną zależność, zob. Saunders i Kirby, „Light-Induced”, 93. Inni autorzy zwracają uwagę, że tempo zachodzenia zmian na początku starzenia jest większe, a następnie spowalnia - ich zdaniem odpowiedzialne za to jest szybsze blaknięcie drobnych cząstek, większe dłużej zachowują swoją barwę, zob. Johnston-Feller et al., „The Kinetics”, 122.

45 Szmit-Naud, „Przyczyny i mechanizmy”, 87.

46 Badania A. Burnstock na przekrojach wykazały ponadto, że w mieszaninie z bielą blaknięcie pigmentów sięga głębiej niż w pełnym tonie, co także jest związane z odbiciem światła od białych cząstek, zob. Burnstock, „The Fading”, 61, 63. 
wczesnym etapie starzenia może być zmiana wyjściowej żółtej barwy spoiwa (odbarwienie) związana z „bieleniem” barwnika w żółtku jaja oraz „bieleniem” oleju, bardziej widoczna w jasnych próbkach z dużą zawartością bieli ${ }^{47}$.

Są jednak w badanym zestawie warstwy, których trwałość okazała się dużo niższa w pełnym tonie niż w rozbiale. Należą do nich warstwy zawierające kraplak, cynober i ultramarynę, czyli te, w których zarejestrowano największe zmiany barwy.

W warstwach z kraplakiem pierwsze zmiany, dostrzegalne już w początkowej fazie starzenia, zachodziły w rozbiałach, co zgadza się z twierdzeniem, że kraplak szybciej blednie w mieszaninie z kryjącą bielą niż w pełnym to$n^{4} \mathrm{e}^{48}$. Jednak pomiary instrumentalne po zakończonym cyklu starzeniowym wykazały większe zmiany barwy w warstwach w pełnym tonie. Za zmianę wyglądu warstwy o pełnym tonie jest odpowiedzialne przede wszystkim znaczne jej pojaśnienie i spadek nasycenia barwy. W znacznie jaśniejszym rozbiale różnice jasności i nasycenia nie były aż tak duże i na całkowitą zmianę barwy miała wpływ przede wszystkim zmiana kąta odcienia. Z przebiegu krzywej odbicia wynika, że po starzeniu zmieniła się charakterystyka widmowa pigmentu. Wcześniej prowadzone badania dowodzą, że rozbiały z zastosowaniem czerwieni alizarynowej nie blakły szybciej niż ciemniejsze warstwy zawierające ten pigment. Według tych badań spadek stężenia alizaryny (utrata barwy) następuje proporcjonalnie, niezależnie od początkowego jej stężenia, co nie jest zgodne z założeniem, że wyższe stężenie zwiększa odporność warstwy. Wynika to z zachowania kinetycznego pierwszego rzędu, zgodnie z którym zachodzą reakcje w warstwach z alizaryną ${ }^{49}$, nie wyjaśnia jednak, dlaczego większe zmiany zaszły w pełnym tonie. Być może istnieje tu związek z procesem produkcji pigmentu. Nierównomierne odbarwianie warstwy olejnej zawierającej kraplak może być spowodowane jej nierówną powierzchnią jako efektem dużej ziarnistości pigmentu. W publikacjach pojawia się także informacja o przyjmowaniu przez warstwy z kraplakiem pośredniej żółtej for-

47 Saunders i Kirby, „Light-Induced”, 90.

48 Saunders i Kirby, „Light-Induced”, 90; Szmit-Naud, „Przyczyny i mechanizmy”, 86.

49 Szybkość, z jaką zachodzi reakcja (pigment traci barwę) jest proporcjonalna do stężenia pigmentu obecnego w danym momencie. Na szybkość reakcji nie mają wpływu stężenia innych pigmentów (w tym przypadku bieli). Zob. Johnston-Feller et al., „The Kinetics”, 115, 124-125. 
my w trakcie płowienia, co można zaobserwować bezpośrednio w obrazach, lecz w omawianym badaniu tego etapu nie zarejestrowano ${ }^{50}$.

W warstwie z cynobrem, która poszarzała, zmiany były związane z wytworzeniem się na jej powierzchni, w wyniku jednoczesnego działania światła i jonów chlorkowych, rtęci metalicznej ${ }^{51}$. W pełnym tonie odnotowano większe zmiany, gdyż warstwa zawierała wyłącznie ten pigment, natomiast mniej widoczne w rozbiale, gdzie jego stężenie było mniejsze. W warstwie $\mathrm{z}$ ultramaryną $\mathrm{w}$ pełnym tonie różnica polegała przede wszystkim na zmianach nasycenia barwy, w rozbiale były one znacznie łagodniejsze ze względu na mniejsze nasycenie wyjściowe, spowodowane dużą zawartością bieli. Bardziej stabilny, chociaż w mniejszym stopniu, okazał się również rozbiał czerwieni żelazowej w temperze.

Z przedstawionych ustaleń wynika, że oprócz rodzaju wykorzystanych materiałów wpływ na światłotrwałość danej warstwy mają także wielkość ziaren pigmentu i jego stężenie, wynikające z zastosowania w pełnym tonie lub z dodatkami (np. w mieszaninie z bielą), a także grubość warstwy malarskiej (przy użyciu pigmentów tworzących warstwy transparentne). Należy także wziąć pod uwagę możliwość interakcji danego pigmentu ze spoiwem oraz dodatkami wprowadzonymi w procesie jego produkcji.

Omówione rezultaty badań ilustrują prawdopodobny kierunek zmian wyglądu - głównie barwy - warstw malarskich niewerniksowanych w procesie ich starzenia. Określenie zmian układu warstwa malarska-werniks wymagałoby przeprowadzenia badań starzeniowych na tych samych warstwach malarskich werniksowanych.

\section{Wnioski końcowe}

Starzenie materiałów spowodowane ekspozycją na działanie światła wywiera znaczący wpływ na wygląd obrazu. Zapewnienie odpowiedniej ochrony wymaga od konserwatora znajomości mechanizmów degradacji użytych materiałów, by móc skutecznie je spowalniać. Wiedza na temat wrażliwości pigmentów zawartych w warstwach malarskich na światło pozwala określić

\footnotetext{
50 Autorzy, którzy odnotowali obecność fazy pośredniej (żółtej) odbarwiania alizaryny w warstwach kryjących z bielą twierdzą, że niezarejestrowanie jej w trakcie procesu starzenia nie oznacza jej braku. Sugerują, że w warstwach półkryjących reakcja ta zachodzi bardzo szybko i przybierają one postać bezbarwną. Zob. Johnston-Feller et al., „The Kinetics”, 119, 127.

51 Anaf, Janssens, i De Wael, “Formation”, 12570.
} 
optymalne warunki przechowywania, w których procesy starzeniowe uda się spowolnić do minimum. Poddanie próbek przyspieszonemu starzeniu pod wpływem światła, jest metodą najadekwatniej odzwierciedlającą starzenie naturalne pod wpływem tego czynnika, niemniej w warunkach naturalnych oddziałują także inne czynniki zewnętrzne. Rezultaty badań pokazały jednak, jakie zmiany kolorystyczne może wywołać oddziaływanie światła i jaki kierunek mogą te zmiany przybrać. Na podstawie badań, ustalono prawdopodobną kolorystykę warstw malarskich bezpośrednio po namalowaniu obrazu. Taka informacja może być przydatna dla konserwatorów, dla historyków sztuki oraz przede wszystkim dla kopistów.

W obrazie, który stał się inspiracją do podjęcia badań, czarny rysunek wykonany farbą składającą się z czerni kostnej - która jest bardzo odporna na działanie światła, a dodatkowo przysłonięta wierzchnimi warstwami chroniącymi ją przed szkodliwym działaniem promieniowana nadfioletowego (UV) - jest bardzo dobrze zachowany. Zniszczenia w jego obrębie nie wynikają ze złej kondycji pigmentu w warstwie rysunku, lecz z przyczyn mechanicznych, tj. odspajania warstwy zaprawy od podłoża, spowodowanego pracą drewnianego podobrazia. Izolacja olejna przykryta wierzchnimi warstwami farby jest mocno pożółkła, co należy wiązać z żółknięciem spoiwa olejnego bez dostępu światła.

Warstwa malarska wydaje się znacząco zmieniona kolorystycznie. Dostrzegalne są różnice w obrębie zarówno oryginalnych, jak i wtórnych materiałów. Aby precyzyjnie określić kierunek zmiany barwy, należałoby wykonać instrumentalne pomiary świeżej warstwy identycznej z oryginalną i zmienionego oryginału, co w warunkach opisanych badań nie było możliwe.

Zażółcenia w partii nieba oraz zazielenienia błękitów w tle w większości nie są spowodowane żółknięciem oleju pod wpływem starzenia. W dużej mierze jest za nie odpowiedzialny pożółkły werniks wtórny, po którego częściowym usunięciu uwidocznił się chłodny odcień tej warstwy. Warstwy z naturalnym azurytem i bielą ołowiową wykazały się dobrą odpornością na światło, a ich zniszczenia na obrazie są spowodowane głównie odspajaniem łusek warstwy malarskiej od podłoża. Warstwa znajdującego się pod retuszem gruboziarnistego azurytu w pełnym tonie jest lekko pożółkła, co może mieć związek z żółknięciem spoiwa bez dostępu światła lub wytworzeniem zielonych mydeł miedziowych ze spoiwem olejnym ${ }^{52}$. Podobnie jak w badaniu

52 Szmit-Naud, „Przyczyny i mechanizmy”, 85. 
starzeniowym, warstwa ta również pociemniała. Wymienione zmiany barwy azurytu mogły przyczynić się do podjęcia decyzji o przemalowaniu tych partii ultramaryną, która miała nadać im chłodniejszy ton. Partie wyretuszowane mają obecnie zielonawy odcień, głównie w dolnej części płaszcza, co przede wszystkim wiąże się ze zżółknięciem werniksu. Zielenie wykonane pigmentami miedziowymi nie są znacząco zmienione kolorystycznie, choć przysłonięte obecnym pożółkłym werniksem są odbierane jako zgniłozielone o ciepłym odcieniu.

Na zniszczenia w obecnie zachowanych partiach czerwieni organicznych mogła mieć wpływ przede wszystkim praca podobrazia, ale także niestabilność barwna tych warstw. Ubytki w obrębie czerwieni są znaczne, zwłaszcza na karminowej sukni Marii, która w większości się nie zachowała. Górne partie sukni, namalowane mieszaniną czerwieni i bieli, pod wpływem działania światła uzyskały odcień różowobeżowy, który pierwotnie mógł być bardziej czerwony. W celu uzyskania chłodnego odcienia szata została namalowana farbą na bazie kraplaku oraz prawdopodobnie karminu, który charakteryzuje się jeszcze mniejszą odpornością na działanie światła niż kraplak ${ }^{53}$; ze względu na uszkodzenia w obrazie trudno to potwierdzić na podstawie obserwacji. Dolna partia sukni jest mocno pociemniała, na co prawdopodobnie miało wpływ pociemnienie spodniej warstwy zawierającej azuryt - podobnie jak w płaszczu Marii.

Rozległe ubytki powstałe w wyniku złuszczenia warstwy malarskiej występują także w partii cieni płaszcza Marii Magdaleny, gdzie cień uzyskano zapewne przez zwielokrotnienie laserunków z czerwieni organicznej. Cienko nałożone laserunki w partiach świateł i półtonach płaszcza są zachowane znacznie lepiej. W istniejących warstwach czerwieni nie zaobserwowano utraty barwy, jest natomiast widoczne zażółcenie tych obszarów. Szata Marii Magdaleny, pomimo obecności w wierzchniej warstwie laserunku żółcieni organicznej z dodatkiem minii, jest dobrze zachowana, prawdopodobnie dzięki zastosowaniu w tej partii lokalnego zabezpieczenia w formie werniksu białkowego.

Zmiany w obrębie cynobru mogą powodować nie tylko ciemnienie i mniej intensywny odcień czerwonych szat (ich barwa mogła być pierwotnie bardziej nasycona), lecz także sinienie karnacji. Z badania wynika również, że cynober - poszarzały na skutek współdziałania światła i jonów chlorkowych (jako

53 Saunders i Kirby, „Light-Induced”, 92. 
zanieczyszczenia powietrza) - zmienia swój odcień także w tzw. technice „fałszywych kolorów” na żółtozielonkawy, w konsekwencji może być w tej technice błędnie identyfikowany, choćby jako kraplak lub czerwień żelazowa.

Podobne zjawisko poszarzenia barwy może występować w obszarach, gdzie zastosowano czerwień żelazową. Na przykład za przyciemnienie w partiach cieni płaszcza Jana może odpowiadać zarówno czerwień żelazowa, jak i cynober, na który została naniesiona. Zmiana barwy czerwieni żelazowej jest szczególnie widoczna w retuszach czerwonych szat wykonanych za pomocą tego pigmentu otrzymanego sztucznie, charakteryzującego się jeszcze mniejszą cząstką od pigmentu naturalnego. Retusze te są wyraźnie pociemniałe i wykazują dostrzegalny spadek nasycenia barwy. Ciemne partie, w których została użyta duża ilość czerni - np. prawy rękaw płaszcza Jana - są dobrze zachowane.

Warstwa z bielą ołowiową, będącą pigmentem dość odpornym na działanie światła - co znajduje potwierdzenie w badaniu - nieznacznie pożółkła. Warstwa ta odznacza się charakterystyczną dla bieli ołowiowej siatką spękań. Jej zniszczenia wywołało przede wszystkim odspajanie się łusek od podłoża. Utrata spoistości warstwy wskutek degradacji spoiwa może mieć wpływ na wykruszanie się warstwy malarskiej, co mogą dodatkowo potęgować ruchy podobrazia.

Na podstawie informacji uzyskanych w toku badań podjęto próbę rekonstrukcji kolorystycznej pierwotnego wyglądu warstw malarskich obrazu, który symuluje il. 9.

Rezultaty starzenia stwierdzone w badaniach nie odtwarzają zmian, jakie można zaobserwować w warstwach malarskich analizowanego dzieła. Zmiany w obrazie są mniej intensywne niż w próbkach warstw malarskich zawierających badane pigmenty. W warunkach ekspozycji warstwy malarskie pochłonęły najprawdopodobniej dawkę napromienienia mniejszą od wyemitowanej w procesie sztucznego starzenia próbek. Badania na próbkach, mimo, że nie odwzorowały intensywności zmian, wskazały jednak ich kierunek. Wywołane przez przyspieszone starzenie pojaśnienie oleju miało wyraźny wpływ na wyniki, tymczasem w warunkach naturalnych proces ten nie mógł zachodzić w taki sposób. Jaśnienie oleju jest wyraźnym ograniczeniem badania, gdyż rzutowało na wygląd warstw, a także na ich ciemnienie przy braku światła. Wpływ procesów zachodzących w spoiwie był widoczny w próbkach z dużą ilością spoiwa. Starzonych próbek nie pokryto żadną warstwą ochronną, eliminując w ten sposób dodatkowy wpływ starzenia się werniksu utrudniający 
interpretację zmian i ich przyczyn. Można przypuszczać, że brak warstwy werniksu mógł mieć wpływ na zmiany zachodzące w próbkach już po ukończeniu starzenia. Rejestrację obrazu zmian po zakończeniu starzenia próbek warstw malarskich i wykonanie pomiarów barwy dzielił nieznaczny odstęp czasu, lecz proces zmian trwał - co uczytelniła dodatkowa, ponowna obrazowa rejestracja zmian dokonana w późniejszym czasie. W przyszłości można rozważyć wykonanie pomiaru i rejestracji obrazowej jednocześnie, również po dłuższym czasie ${ }^{54}$, w celu osiągnięcia lepszej korelacji (wyników pomiarów i zarejestrowanego obrazu zmian).

Uwzględnienie wyników bezpośredniej obserwacji powierzchni, informacji uzyskanych w trakcie badań starzonych próbek i efektów dokonanej symulacji prowadzi do wniosku, że na obecny wygląd warstwy malarskiej badanego obrazu w największym stopniu rzutują zniszczenia spowodowane czynnikami mechanicznymi, takimi jak ruchy podobrazia. Zminimalizowanie ich wpływu wymagałoby utrzymania wilgotności względnej powietrza na stałym poziomie.

Kolorystykę zakłóca przede wszystkim zżółknięty werniks na powierzchni obrazu, który jest dodatkowo mocno spękany. Możliwe zmiany barwne poszczególnych oryginalnych warstw malarskich, prześledzone na podstawie przeprowadzonych badań próbek, zdają się mieć mniejszy wpływ. Negatywnie na odbiór dzieła oddziałują także zmienione w wyniku procesów starzenia retusze warstwy malarskiej, które wyraźnie odcinają się od warstw oryginalnych. Ubytki warstwy malarskiej zostały uzupełnione w sposób imitatorski z uwzględnieniem zmienionej już warstwy malarskiej. Zastosowano spoiwo olejne, którego reaktywność jest największa w pierwszych pięćdziesięciu latach, a najbardziej intensywne zmiany są dostrzegane w ciągu dziesięciu lat ${ }^{55}$. Procesy starzenia warstw malarskich mogą zostać spowolnione przez zastosowanie odpowiedniego werniksu, który nie będzie zaburzał odbioru dzieła, a jednocześnie zapewni odpowiednią ochronę powierzchni ${ }^{56}$. Werniks nie daje jednak pełnego zabezpieczenia, ponieważ jego powłoka jest częściowo przezroczysta nie tylko dla promieniowania widzialnego, ale i dla promieniowania $\mathrm{UV}^{57}$. Obraz można uchronić przed szkodliwym działa-

\footnotetext{
54 Niewykonane z powodu ograniczeń czasowych.

55 Szmit-Naud, „Przyczyny i mechanizmy”, 84.

56 Obszerne badania nad współczesnymi werniksami zob. Jerzy Ciabach, Badania dotyczące starzenia i stabilizacji współczesnych werniksów malarskich (Toruń: Wydawnictwo UMK, 1994).

57 De la Rie, „Fluorescence” (Part III), 104.
} 
niem tego promieniowania stosując odpowiednie filtry i właściwe sztuczne oświetlenie.

"Autorzy pragną podziękować Pani dr Agnieszce Morawińskiej, dyrektor Muzeum Narodowego w Warszawie, za udostępnienie obrazu z kolekcji do badań i materiałów. Serdecznie podziękowania kierują także do Pana prof. dr hab. Antoniego Ziemby, kuratora Zbiorów Dawnej Sztuki Europejskiej, Pani dr Grażyny Bastek, kustosz Malarstwa Włoskiego Zbiorów Dawnej Sztuki Europejskiej, Pani mgr Doroty Ignatowicz-Woźniakowskiej, głównej konserwator, Pani mgr Agnieszki Czubak, zastępcy głównego konserwatora, Pani mgr Aleksandry Janiszewskiej, kustosz Zbiorów Dawnej Sztuki Europejskiej, oraz Pani konserwator mgr Iwony Stefańskiej.

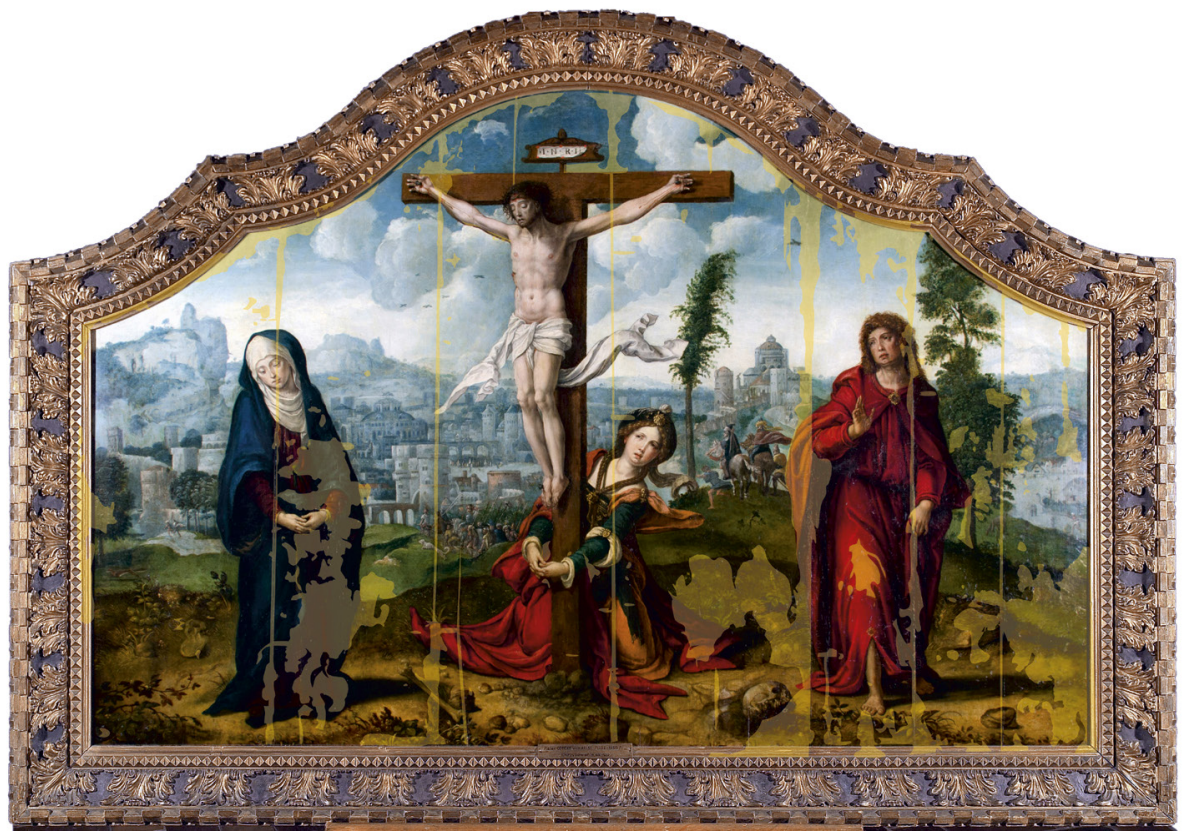

Il. 1. Zakres uzupełnień ubytków warstwy malarskiej na licu. Fot. A. Cupa, oznaczenie ubytków M. Kęsy 


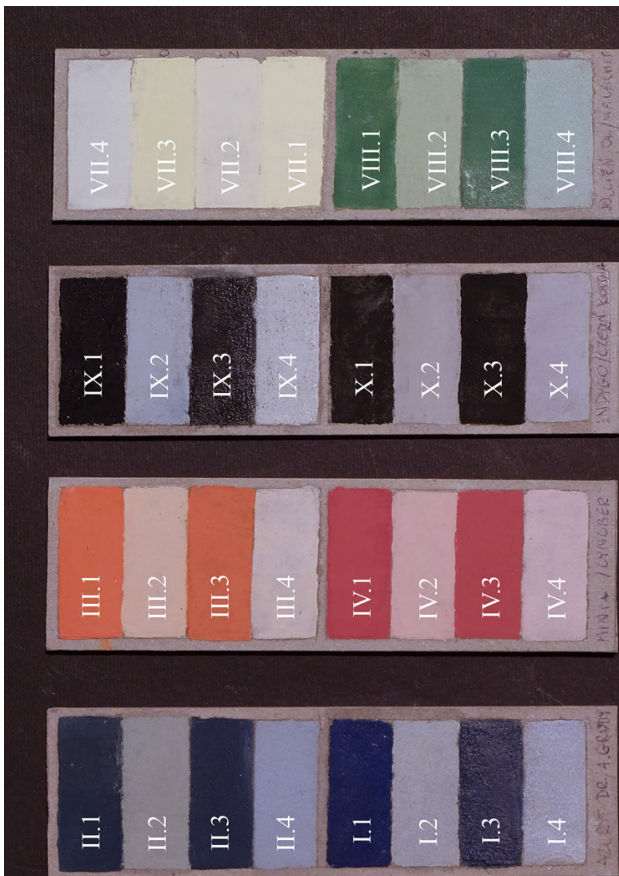

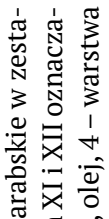

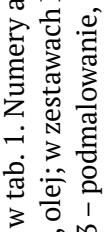

$:=\hat{\pi}^{m}$

营 䨝

घ 잉

齐

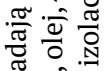

.

चे

둥

웜

药

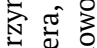

帘 范

离兄

之离悹

ํㅗㅇ

प्

ग 1

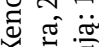

入

3 웡

돈

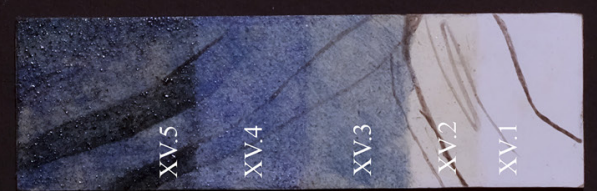

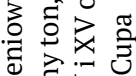

릴

要

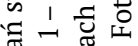

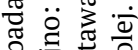

० $\frac{\pi}{0}$
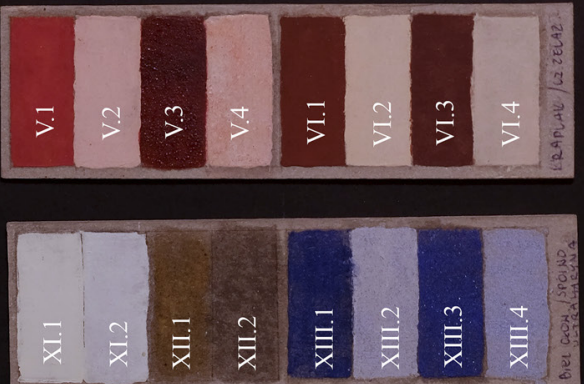

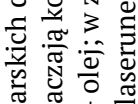

즐 1

घ $\mathrm{N}$ in

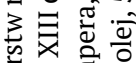

, 更

3 岱

푼

임

i

$\doteq$ 


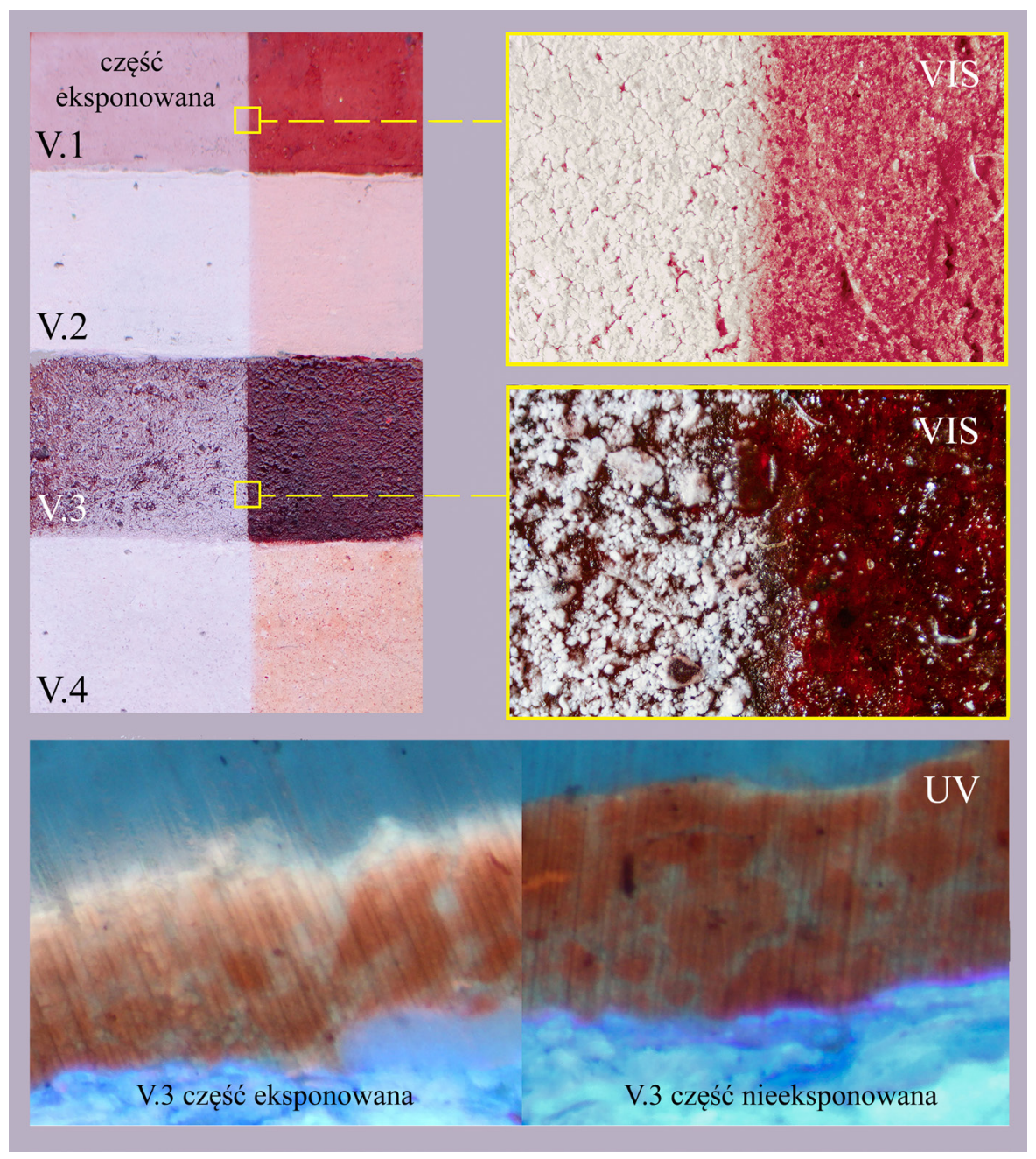

Il. 3. Zmiany zestawu V. Kraplak. Fot. M. Kęsy 


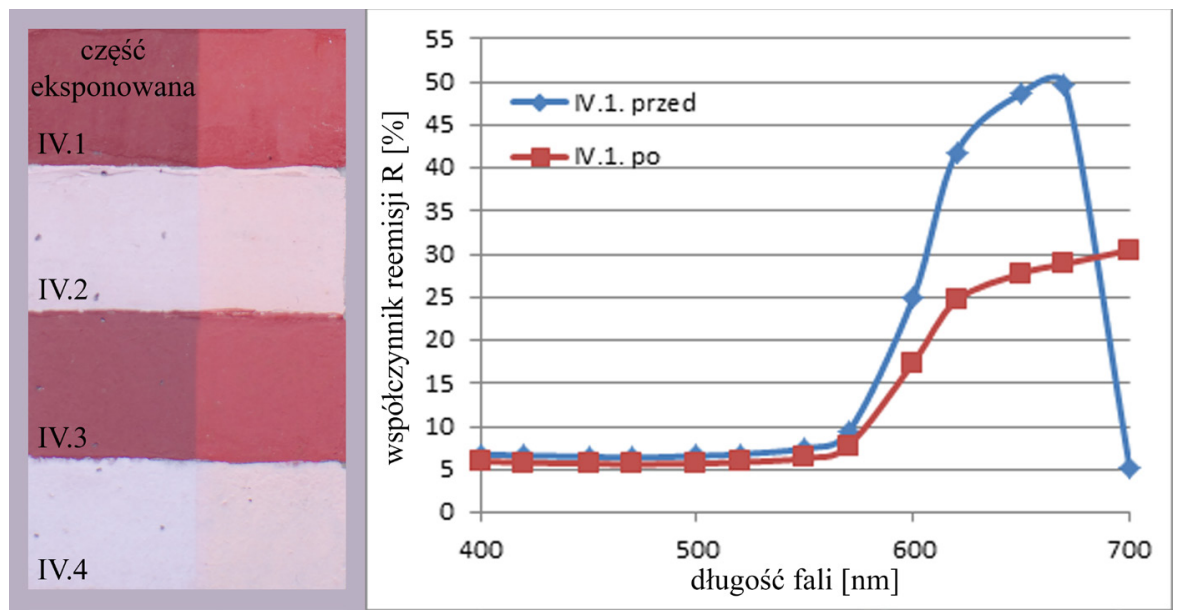

Il. 4. Zmiany barwy po starzeniu zestawu IV. Cynober. Wykres zmian krzywej odbicia próbki IV.1 przed i po starzeniu. Fot. M. Kęsy

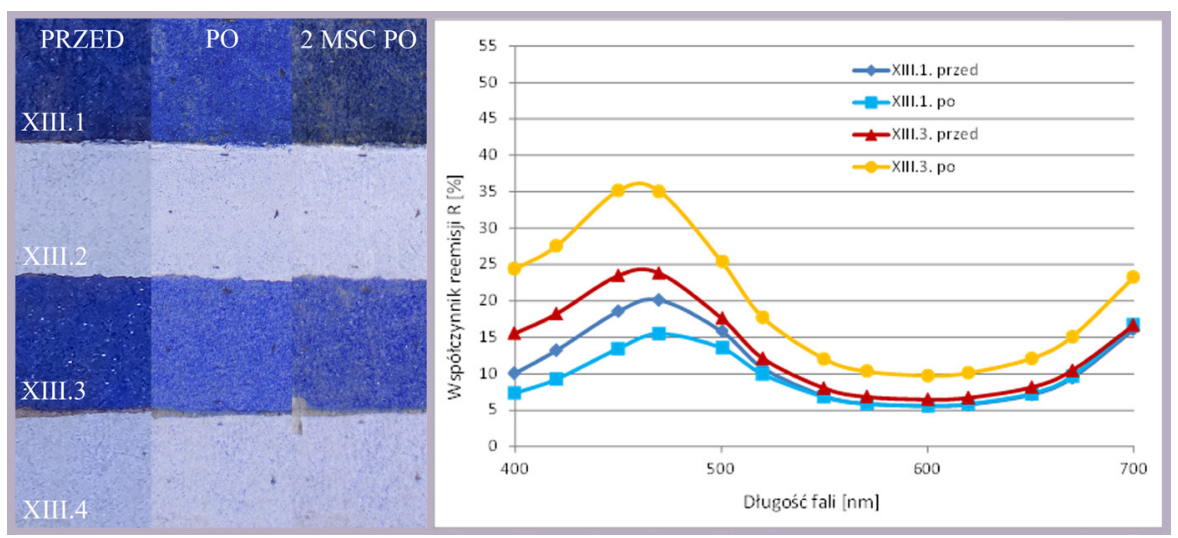

Il. 5. Zmiany barwy po starzeniu zestawu XIII. Ultramaryna. Wykres zmian krzywej odbicia próbek XIII.1 i XIII.3 przed i po starzeniu. Fot. M. Kęsy 


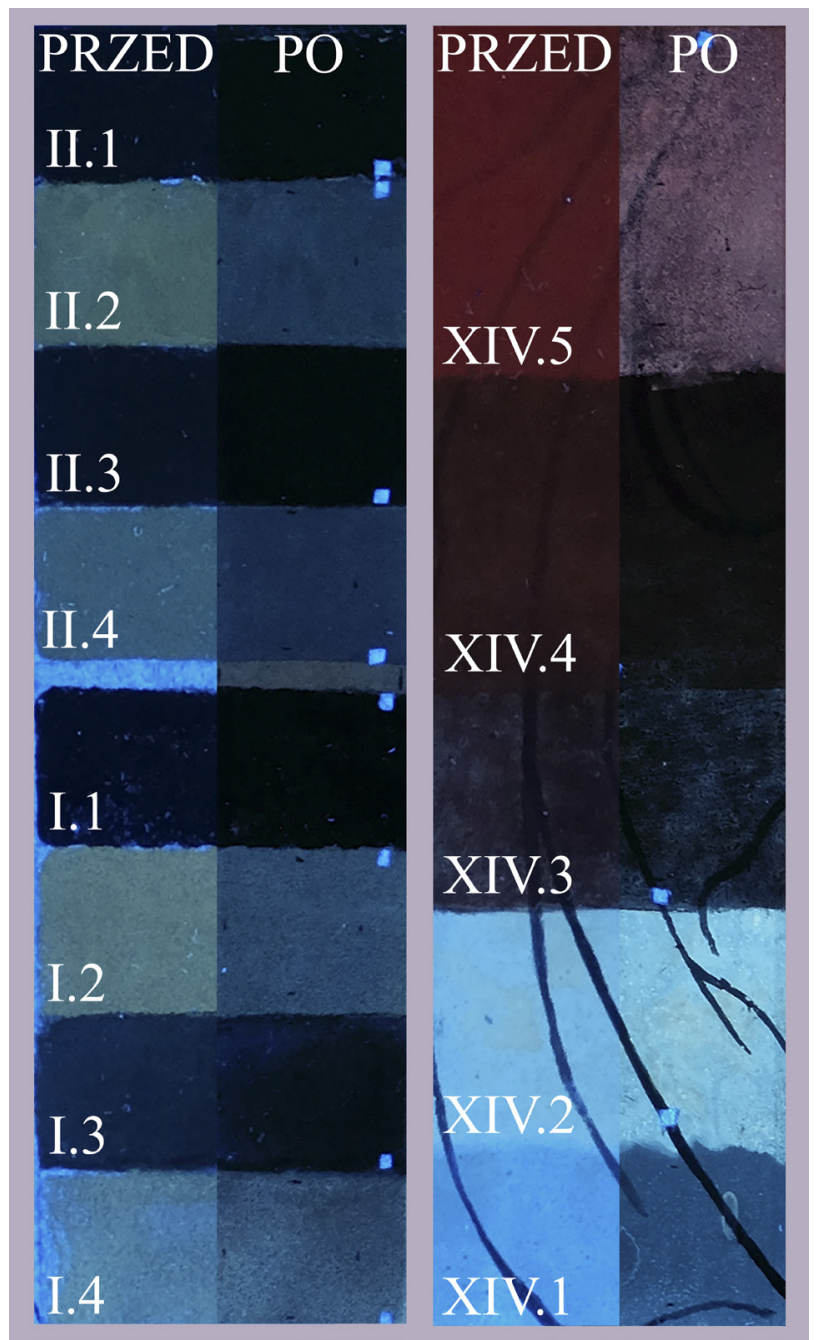

Il. 6. Zmiany fluorescencji wzbudzonej promieniowaniem UV zestawów I. Azuryt gruby i XIV. Czerwień przed i po starzeniem. Fot. A. Cupa 


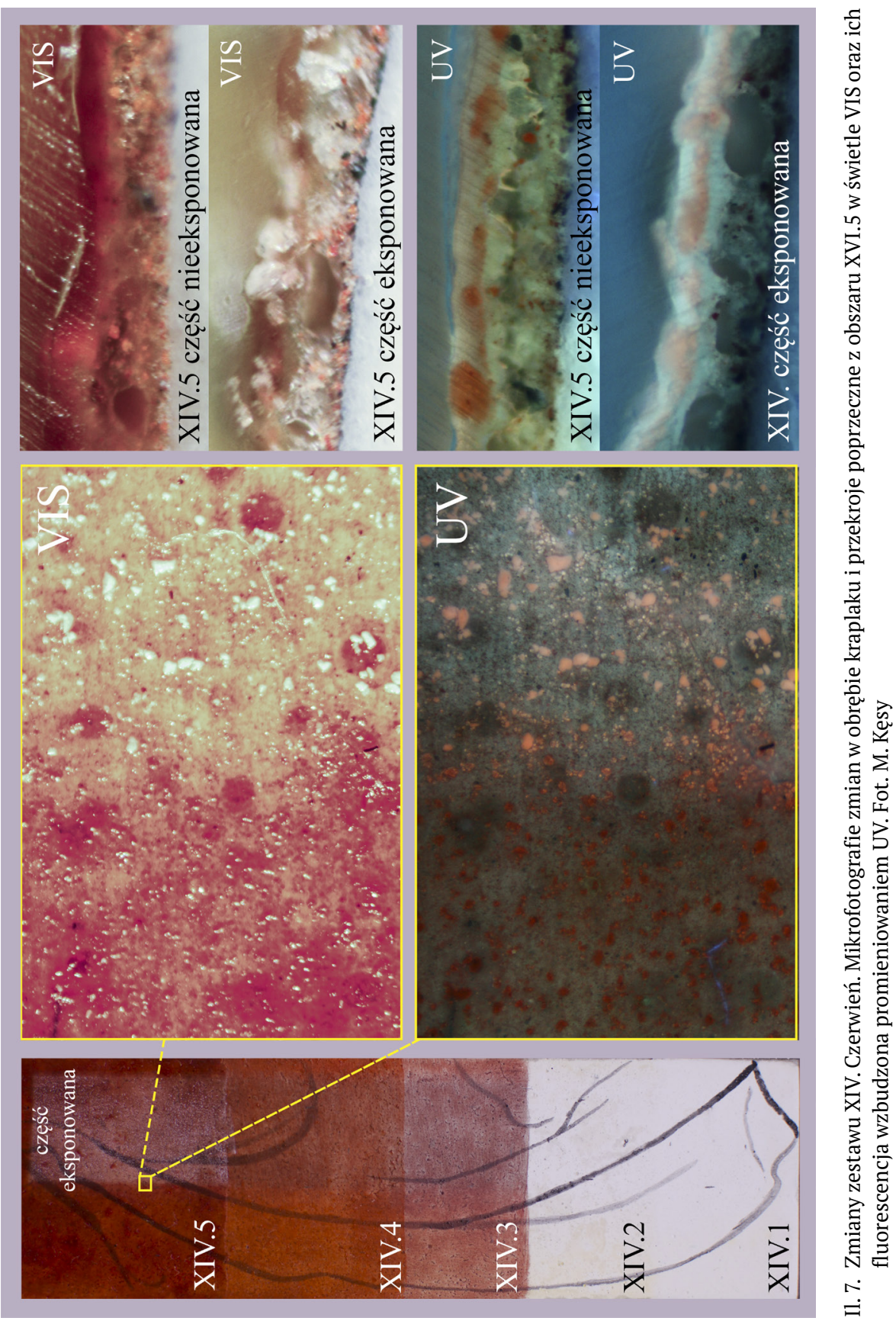




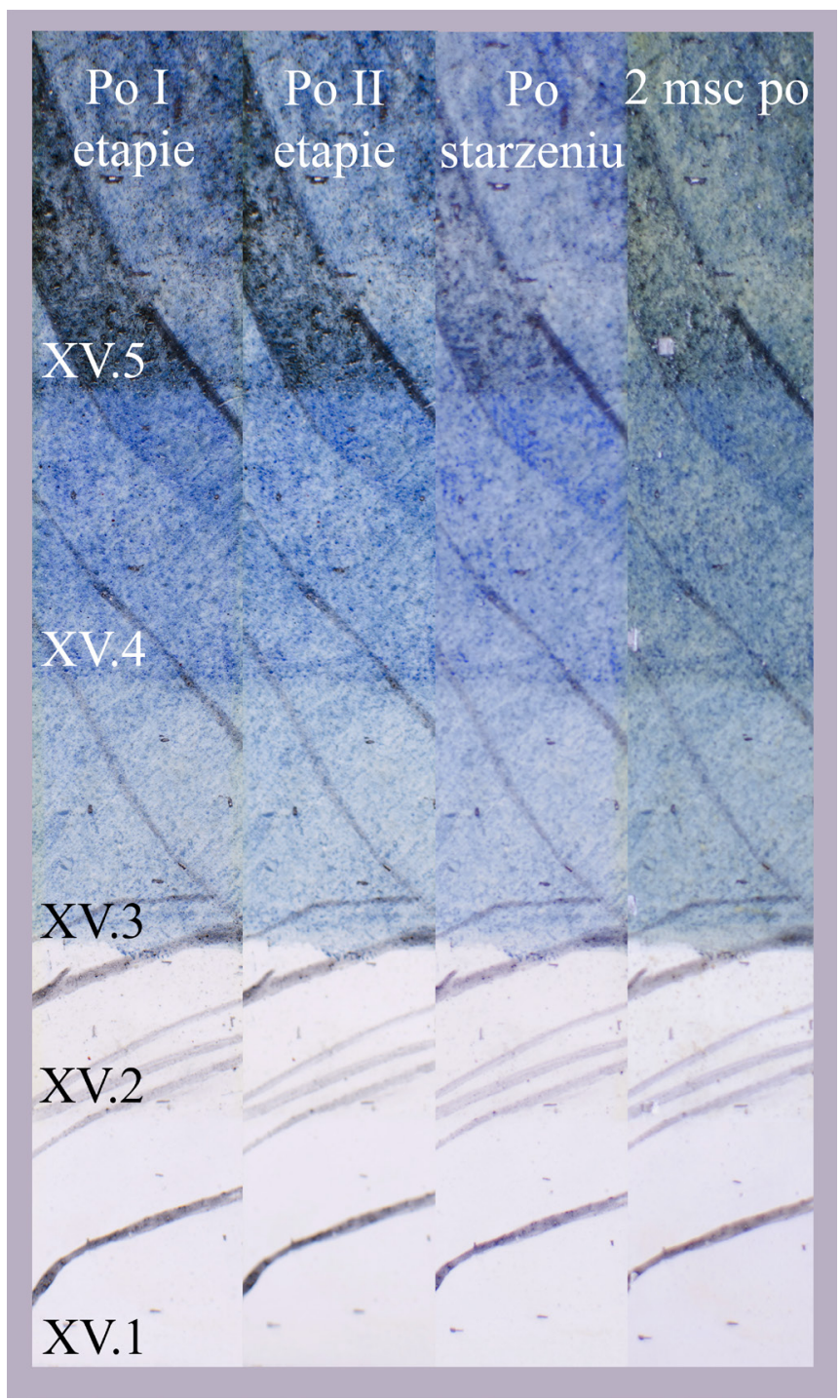

Il. 8. Zmiany zestawu XV. Błękit w trakcie i po starzeniu. Fot. M. Kęsy 


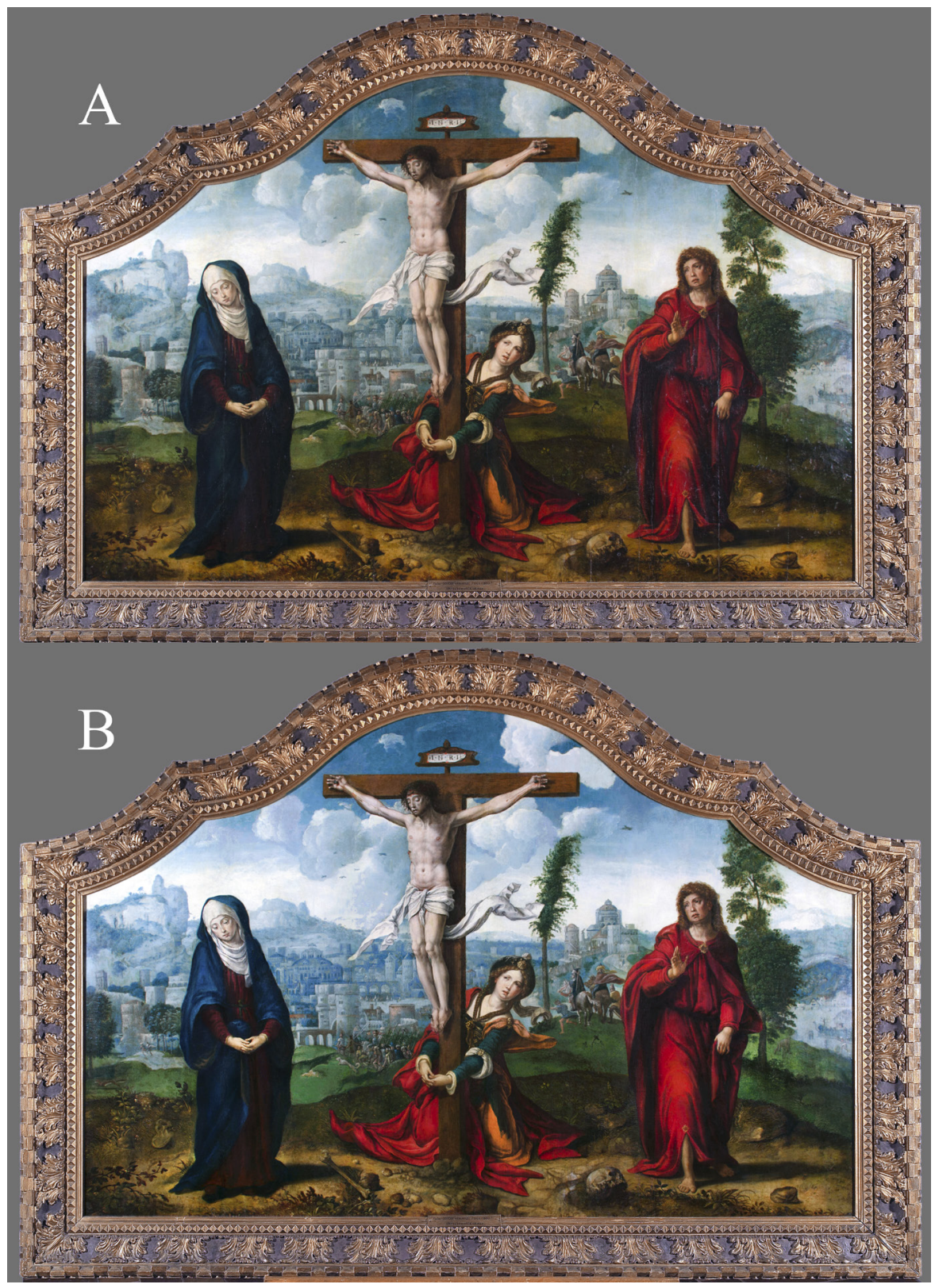

Il. 9. Rekonstrukcja barwna obrazu Ukrzyżowanie. A: obecna kolorystyka, B: prawdopodobna kolorystyka świeżej warstwy malarskiej. Fot. A. Cupa, rekonstrukcja M. Kęsy 


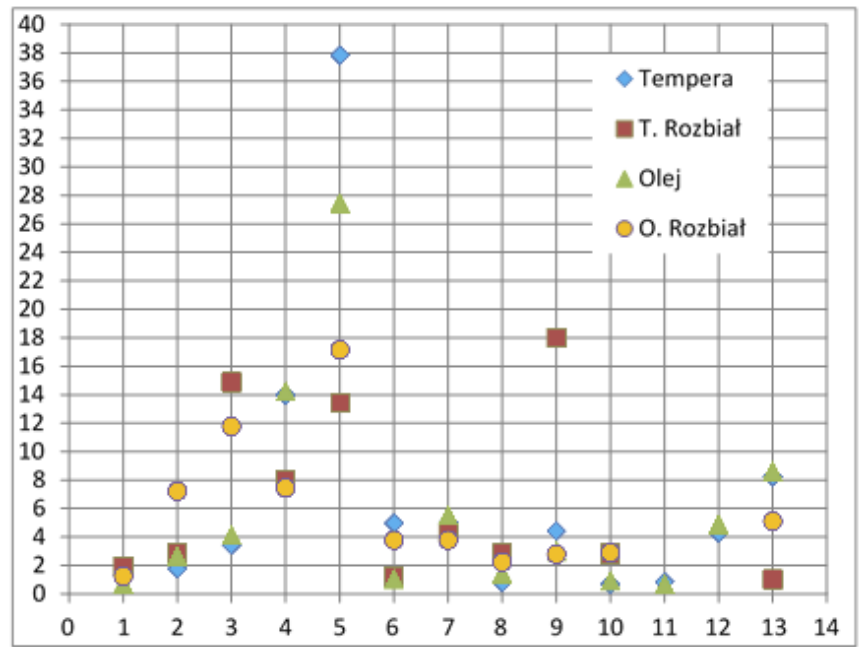

Wykres 1 . Zmiany barwy $\Delta \mathrm{E}^{*}$ zestawów badanych próbek. Oś pionowa określa zakres zmian; oś pozioma określa numer próbki, gdzie 1 odpowiada zestawowi I, 2-II. Itd.

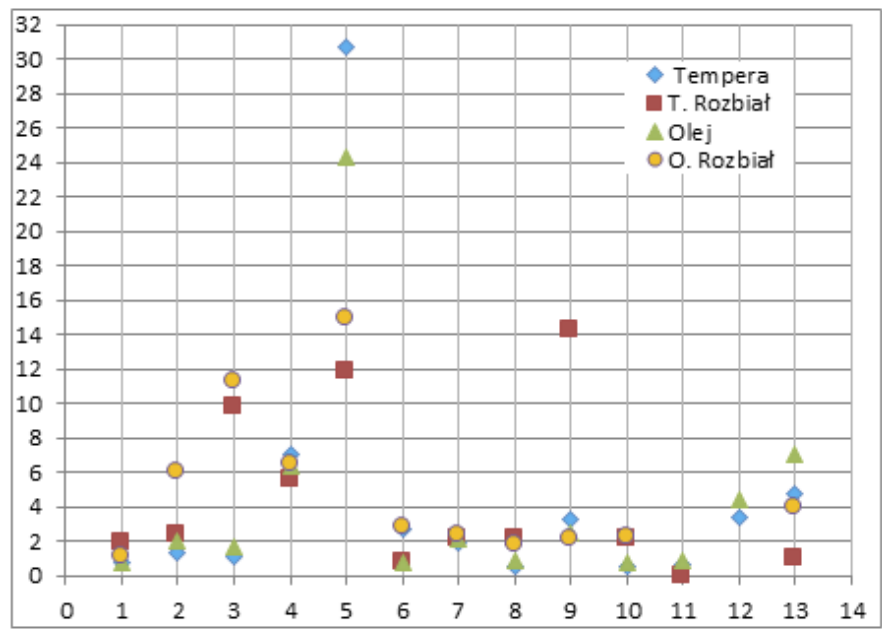

Wykres 2 . Zmiany barwy $\Delta \mathrm{E} 2000$ zestawów badanych próbek. Oś pionowa określa zakres zmian; oś pozioma określa numer próbki, gdzie 1 odpowiada zestawowi I, 2-II. Itd. 


\section{Bibliografia:}

Anaf, Willemien, Koen Janssens, i Karolien De Wael. „Formation of Metallic Mercury During Photodegradation / Photodarkening of a-HgS: Electrochemical Evidence”. Angewandte Chemie International Edition 52 (2013): 12568-12571.

Benesz, Hanna, i Maria Klug. Early Netherlandish, Dutch, Flemish and Belgian Paintings 1494-1983 in the Collections of the National Museum on Warsaw and the Palace at Nieborów. Complete Illustrated Summary Catalogue. T. 1 Signed and attributed paintings, red. Agnieszka Morawińska. Warsaw: The National Museum in Warsaw, 2016.

Brochwicz, Zbigniew. „Interpretacja siarczanu ołowiawego PbSO4 w trakcie identyfikacji barwników organicznych w zabytkowych obiektach polichromowanych”. Materiały Muzeum Budownictwa Ludowego w Sanoku 23 (1977): 44-45.

Burnstock, Aviva. „The Fading of the Virgin's Robe in Lorenzo Monaco's 'Coronation of the Virgin’”. National Gallery Technical Bulletin 12 (1988): 58-65.

Cennini, Cennino. Rzecz o malarstwie. Florencja: Florencka Oficyna Tyszkiewiczów, 1933.

Ciabach, Jerzy. Badania dotyczące starzenia i stabilizacji współczesnych werniksów malarskich. Toruń: Wydawnictwo UMK, 1994.

De la Rie, E. René. „Fluorescence of Paint and Varnish Layers (Part I, II, III). Studies in Conservation 27, no. 1, 2, 3 (1982): 1-7, 65-69, 102-108.

Giles, Charles H., David J. Walsh, i Rou S. Sinclair. „The Relation between Light Fastness of Colorants and their Particle Size”. Coloration Technology 93, no. 9 (1977): 348-352.

Golden Artist Colors. „Product information sheet”. Dostęp October 27, 2017. https:// www.goldenpaints.com/technicalinfo_msapaint.

Górzyńska, Małgorzata, i Justyna Olszewska-Świetlik. „Wybrane żółte laki: rekonstrukcja technologiczna”. Biuletyn Informacyjny Konserwatorów Dzieł Sztuki 13, no. 1-2 (2002): 26-33.

Holley, Clifford Dyer. The Lead and Zinc Pigments. New York: John Wiley \& Sons, 1909. Johnston-Feller, Ruth, Robert L. Feller, Catherine W. Bailie, i Mary Curran. „The Kinetics of Fading: Opaque Paint Films Pigmented with Alizarin Lake and Titanium Dioxide”. Journal of the American Institute for Conservation 23, no. 2 (1984): 114-129.

Kęsy, Monika. „Obraz ‘Ukrzyżowanie’ Pietera Coecke’a van Aelst (1502-1550) - analiza technologii i techniki malarskiej jako przyczynek do określenia zmian pierwotnej kolorystyki dzieła”. Praca magisterska, UMK w Toruniu, 2017.

Olszewska-Świetlik, Justyna, i Zuzanna Rozłucka. „Badania czerwonych laserunków metodą mikroskopii fluorescencyjnej UV”. Acta Universitatis Nicolai Copernici. Zabytkoznawstwo i Konserwatorstwo 34 (2005): 141-160.

Prezbiter, Teofil. Diversarum Artium Schedula. Średniowieczny zbiór przepisów o sztukach rozmaitych. Tłumaczenie Stanisław Kobielus. Kraków: Wydawnictwo Benedyktynów Tyniec, 1998. 
Rozłucka, Zuzanna, Maria Roznerska, i Joanna Arszyńska. Mikroskopia fluorescencyjna. Toruń: Wydawnictwo UMK, 2000.

Rudniewski, Piotr. Pigmenty i ich identyfikacja, Warszawa: ASP, 1994.

Saunders, David, i Jo Kirby. "Light-Induced Colour Changes in Red and Yellow Lake Pigments”. National Gallery Technical Bulletin 15 (1994): 79-97.

Szmit-Naud, Elżbieta. „Farby dla konserwatorów malarstwa - właściwości aplikacyjne i stabilność". Ochrona Zabytków 3 (2007): 59-67.

Szmit-Naud, Elżbieta. „Przyczyny i mechanizmy zmian wyglądu uzupełnień warstw malarskich w obrazach sztalugowych”. Ochrona Zabytków 1-2 (2003): 73-88.

Szmit-Naud, Elżbieta. „Rozpuszczalnikowe farby przeznaczone do uzupełnień ubytków warstwy malarskiej - właściwości aplikacyjne i stabilność w procesie starzenia”. W Badania technologii i technik malarskich, konserwacja dzieł sztuki, kopia. Księga pamiątkowa z okazji jubileuszu 50-lecia pracy dedykowana prof. dr. art. kons. Józefowi Flikowi, red. Justyna Olszewska-Świetlik, 299-309. Toruń: Wydawnictwo UMK, 2007.

Szmit-Naud, Elżbieta. „Uzupełnienia ubytków warstwy malarskiej obrazów - badania materiałów stosowanych współcześnie”. Acta Universitatis Nicolai Copernici. Zabytkoznawstwo i Konserwatorstwo 34 (2005): 65-102.

Szmit-Naud, Elżbieta. Uzupełnienia ubytków warstwy malarskiej obrazów. Zmiany optyczne a stabilność stosowanych materiałów. Toruń: Wydawnictwo UMK, 2006.

Szmit-Naud, Elżbieta. „Wrażenie barwy i klasyfikacja barw. Ocena zmian barwy materiałów stosowanych w konserwacji dzieł sztuki”. Acta Universitatis Nicolai Copernici. Zabytkoznawstwo i Konserwatorstwo 34 (2005): 39-63.

Szmit-Naud, Elżbieta. „Zmiany optyczne retuszy w malarstwie sztalugowym”. Rozprawa doktorska, UMK w Toruniu, 2001.

Whitmore, Paul M., i Catherine Bailie. „Further Studies on Transparent Glaze Fading: Chemical and Appearance Kinetics". Journal of the American Institute for Conservation 36, no. 3 (1997): 207-230. 